ARTICLE

\title{
$\beta$-sitosterol ameliorates influenza A virus-induced proinflammatory response and acute lung injury in mice by disrupting the cross-talk between RIG-I and IFN/STAT signaling
}

\author{
Bei-xian Zhou' ${ }^{1}$, Jing Li ${ }^{2}$, Xiao-li Liang ${ }^{2}$, Xi-ping Pan ${ }^{3}$, Yan-bing Hao ${ }^{2}$, Pei-fang Xie ${ }^{2}$, Hai-ming Jiang ${ }^{2}$, Zi-feng Yang ${ }^{2,4,5}$ and \\ Nan-shan Zhong ${ }^{2,4}$
}

$\beta$-Sitosterol (24-ethyl-5-cholestene-3-ol) is a common phytosterol Chinese medical plants that has been shown to possess antioxidant and anti-inflammatory activity. In this study we investigated the effects of $\beta$-sitosterol on influenza virus-induced inflammation and acute lung injury and the molecular mechanisms. We demonstrate that $\beta$-sitosterol $(150-450 \mu \mathrm{g} / \mathrm{mL}) \mathrm{dose}-$ dependently suppresses inflammatory response through NF-KB and p38 mitogen-activated protein kinase (MAPK) signaling in influenza A virus (IAV)-infected cells, which was accompanied by decreased induction of interferons (IFNs) (including Type I and III IFN). Furthermore, we revealed that the anti-inflammatory effect of $\beta$-sitosterol resulted from its inhibitory effect on retinoic acidinducible gene I (RIG-I) signaling, led to decreased STAT1 signaling, thus affecting the transcriptional activity of ISGF3 (interferonstimulated gene factor 3) complexes and resulting in abrogation of the IAV-induced proinflammatory amplification effect in IFNsensitized cells. Moreover, $\beta$-sitosterol treatment attenuated RIG-I-mediated apoptotic injury of alveolar epithelial cells (AEC) via downregulation of pro-apoptotic factors. In a mouse model of influenza, pre-administration of $\beta$-sitosterol $\left(50,200 \mathrm{mg} \cdot \mathrm{kg}^{-1} \cdot \mathrm{d}^{-1}\right.$, i.g., for 2 days) dose-dependently ameliorated IAV-mediated recruitment of pathogenic cytotoxic T cells and immune dysregulation. In addition, pre-administration of $\beta$-sitosterol protected mice from lethal IAV infection. Our data suggest that $\beta$-sitosterol blocks the immune response mediated by RIG-I signaling and deleterious IFN production, providing a potential benefit for the treatment of influenza.

Keywords: influenza A virus; $\beta$-sitosterol; RIG-I; IFN- $\beta$; anti-inflammatory; acute lung injury

Acta Pharmacologica Sinica (2020) 41:1178-1196; https://doi.org/10.1038/s41401-020-0403-9

\section{INTRODUCTION}

The annual spread of seasonal influenza A virus (IAV), particularly the sporadic transmission of highly pathogenic avian influenza (HPAl) viruses (e.g., the H5N1 and H7N9 subtypes) continues to constitute a major threat to public health. As of December 2018, avian influenza A H7N9 viruses have caused an estimated 1567 individual infections, with an overall mortality rate of $39.2 \%$ (http://www.fao.org/ag/againfo/programmes/en/empres/h7n9/ situation_update.html). Recently, the NA R292K and NS G540A substitutions in the H7N9 virus have been reported to be associated with increased resistance to oseltamivir and to confer enhanced viral replication in mammalian cells [1, 2]. This raises concerns about a potential human pandemic. IAV initiates infection in humans via entry through the upper respiratory tract, eliciting symptoms that can be mild and self-limited, but in some patients, it can lead to acute respiratory distress syndrome (ARDS), which is characterized by the impairment of gas exchange resulting in a fatal outcome [3, 4]. A series of reports have indicated that a robust and dysregulated innate immune response is primarily responsible for the high mortality rate associated with influenza $[5,6]$. However, there are few alternative medicine strategies available for the treatment of influenza virus-infected patients who have an intense inflammatory response.

The innate immune system is armed with an array of pattern recognition receptors (PRRs) that provide the principal barrier defense against infectious agents [7]. During the process of viral replication, influenza virus synthesizes viral RNA containing a $5^{\prime}$ triphosphate end and is then transported to the cytoplasm [8]. This pathogen-associated molecule (PAM) is detected by the cytosolic sensor retinoic acid-induced gene I (RIG-I) and

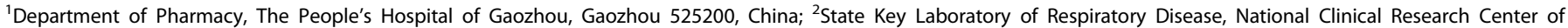

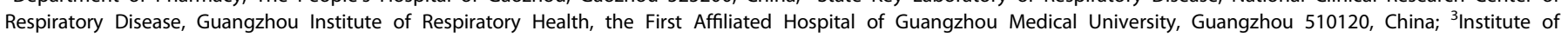

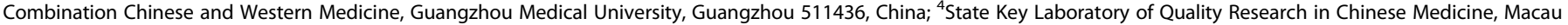

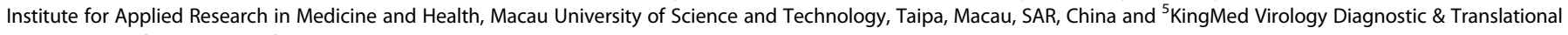
Center, Guangzhou 510320, China

Correspondence: Zi-feng Yang (Jeffyah@163.com) or Nan-shan Zhong (nanshan@vip.163.com)

These authors contributed equally: Bei-xian Zhou, Jing Li, Xiao-li Liang, Xi-ping Pan

Received: 20 September 2019 Accepted: 17 March 2020

Published online: 5 June 2020 
subsequently activates multiple cellular signal cascades [9]. Ultimately, these signaling pathways lead to the activation of transcription factors including NF-KB, AP-1 (ATF2:C-jun), and IRF3, which together bind to specific sites of the IFN- $\beta$ promoter and initiate IFN- $\beta$ synthesis for the antiviral response [10]. Targeting p38 MAP kinase with a specific inhibitor affects the induction of IFN- $\beta$ [11], which inhibits the downstream phosphorylation of ATF2 by p38 MAP kinase [12]. Studies have demonstrated the crucial role of IFN production mediated by RIG-I signaling in protecting against lethal IAV challenge $[13,14]$. In vivo studies have shown that the increased susceptibility of both RIG-I- and IFN-deficient mice to several RNA viruses [15-17], including vesicular stomatitis virus (VSV), Newcastle disease virus (NDV), and IAV, is associated with the failure of IFNs levels to increase or a lack of IFN signaling. There is evidence that infection with HPAI $\mathrm{H} 5 \mathrm{~N} 1$ viruses triggers the hyperinduction of proinflammation via RIG-I signaling cascades despite the crucial role of RIG-I signaling in defense against IAV [18]. The induction of downstream genes of RIG-I signaling, such as IL-6, TNF- $\alpha$, IL- 8 , and IL- $1 \beta$, is significantly upregulated in the bronchoalveolar lavage fluid (BALF) of patients with sustained ARDS $[3,19,20]$.

Type I and type III IFNs secreted by infected cells bind to distinct receptors but trigger similar signal transduction through the JAK/ STAT cascades [21, 22]. Upon IFN stimulation, the phosphorylation of the STAT1:STAT2 heterodimer leads to its interaction with IRF9 and the formation of the interferon-stimulated gene factor 3 (ISGF3) complex [23]. Then, the complex moves from the cytoplasm to the nucleus where it binds to the interferonstimulated response element (ISRE) and drives the expression of interferon-stimulated genes (ISGs). These genes possess direct antiviral and immunomodulatory activity [24]. For example, the Mx protein, which was the first ISG identified to restrict influenza virus infection to be identified, has been demonstrated to impair vRNP nuclear import [25]. However, despite the abundant production of IFNs and hundreds of ISGs in response to viral infection, the IFNmediated antiviral response is blocked by various viral products. The non-structural (NS1) protein of IAV is a typical multifunctional protein involved in the blockade of the antiviral effect of ISGs, such as $2^{\prime}, 5^{\prime}$-oligoadenylate synthetase (OAS) and dsRNAdependent protein kinase $\mathrm{R}$ (PKR) $[26,27]$. In addition, IAV infection has also been shown to suppress the antiviral response mediated by type I and III IFNs by upregulating the negative regulators SOCS3 and SOCS1 [28, 29]. Given that viruses can overcome the IFN-mediated antiviral response through various mechanisms, it is possible that excessive IFN production during the antiviral response may contribute to the harmful effects. Surprisingly, studies have found that increased host susceptibility to secondary bacterial co-infections correlates with IFN induction during IAV infection [30]. Moreover, a deficiency in IFN- $\alpha / \beta$ signaling increases survival through a reduction in excessive inflammation and apoptotic injury to lung epithelial cells [31]. Similarly, high levels of TRAIL in BALF collected from patients with influenza-associated ARDS may be a result of increased TRAIL expression induced by macrophage-derived IFN- $\beta$ [32], which contributes to lung alveolar epithelial cell injury. In addition, recent evidence has also revealed that IFN-mediated signaling drives immunopathologic injury in response to various viral infections, including respiratory syncytial virus infection (RSV) [33] and severe acute respiratory syndrome CoV (SARS-CoV) [34]. Given these findings, it is clear that the disease-promoting effects of IFN contribute to deleterious outcomes, and should be limited by pharmacological intervention.

The identification of agents derived from medicinal plants that can prevent influenza is valuable. Chinese medicinal plants, including Lonicera japonica [35], Chrysanthemum morifolium [36], Taraxacum mongolicum [37], Forsythia suspense [38], and Isatis indigotica [39] have been prescribed for the common cold, heatclearing, and detoxication for thousands of years, but the bioactive ingredients of these plants that mediate these pharmacological effects is unknown. Phytosterols contain structural features that resemble those of cholesterol and are abundant in vegetables, fruits, and medicinal plants [40, 41]. Among phytosterols, $\beta$-sitosterol (24-ethyl-5-cholestene-3-ol) is the most common sterol and has been shown to possess antioxidant, antiinflammatory, antitumor, and antiasthmatic effects [42-45]. In the present study, we hypothesized that $\beta$-sitosterol is the bioactive component of five types of medicinal plants. To test this hypothesis, we investigated the effects of $\beta$-sitosterol and the underlying mechanisms by which it may exert a therapeutic effect against influenza-mediated injury and dysregulated inflammation.

\section{MATERIALS AND METHODS}

Preparation of extracts and quantitative analysis of $\beta$-sitosterol Samples of four kinds of different heat-clearing and detoxifying traditional Chinese medicines samples (L. japonica, C. morifolium, T. mongolicum, and F. suspense) were purchased from local markets in Bozhou, China. I. indigotica was supplied by Hutchison Whampoa Guangzhou Baiyunshan Chinese Medicine Co., Ltd (Guangzhou, China). A $\beta$-sitosterol standard was purchased from Sigma (San Francisco, USA), and HPLC-grade methanol was purchased from Fisher Scientific (Fisher, USA).

A sample of each of the five medicinal materials was crushed into a coarse powder, and $2.0 \mathrm{~g}$ was placed in a $100-\mathrm{mL}$ flask. Extraction was performed using ultrasonic waves for $15 \mathrm{~min}$ and the addition of $50 \mathrm{~mL}$ of chloroform and was repeated three times. The samples were then centrifuged at $2500 \times g$ for $10 \mathrm{~min}$. The supernatants were combined and condensed to a proper volume under reduced pressure, and then the concentrates were dissolved with chloroform. The samples were transferred to $5-\mathrm{mL}$ volumetric flasks, diluted with chloroform to $5 \mathrm{~mL}$, and mixed.

A total of $2.0 \mathrm{mg}$ of the $\beta$-sitosterol standard was accurately weighed and dissolved in $5 \mathrm{~mL}$ of chloroform to produce individual stock solutions. HPLC analysis of $\beta$-sitosterol was performed at $28^{\circ} \mathrm{C}$ on an HPLC instrument (Shimadzu 20A, Japan) with a DAD detector at $205 \mathrm{~nm}$. Chromatographic separation was performed on a Shimadzu ODS column $(4.6 \times 150 \mathrm{~mm}, 5 \mu \mathrm{m}$, Tokyo, Japan). The mobile phase was methanol, and the injection volume was $10 \mu \mathrm{L}$. The samples were subjected to quantitative analysis, which was performed using the external standard method. The results are expressed as $\mathrm{mg} / \mathrm{g}$, and all analyses were performed in triplicate.

\section{Virus}

Influenza A/Puerto Rico/8/34 (H1N1) and A/FM/1/47(H1N1) mouse-adapted viruses were stored in our laboratory and propagated in the allantoic cavities of 9-day-old specific pathogen-free embryonated chicken eggs at $37^{\circ} \mathrm{C}$. Freshly collected allantoic fluids were clarified by low-speed centrifugation at $72 \mathrm{~h}$ postinoculation and then stored in small aliquots at $-80^{\circ} \mathrm{C}$. The virus titers were determined using a plaque forming assay in monolayers of Madin-Darby canine kidney (MDCK) cells as previously described.

\section{Mouse experiments and viral challenge}

Four- to six-week-old female BALB/c mice (weighing 16-18g) were purchased from Guangdong Medical Laboratory Animal Center. All mice were housed and cared for under specific pathogen-free conditions at the State Key Laboratory of Respiratory Disease or Guangdong Laboratory Animal Monitoring Institute. All animal experimental procedures in this study were approved by the Ethics Committee of the First Affiliated Hospital of Guangzhou Medical University and conducted in strict accordance with the approved guidelines. The $50 \%$ lethal dose $\left(L D_{50}\right)$ of the mouse-adapted $\mathrm{H} 1 \mathrm{~N} 1$ virus was estimated in mice after the stock virus was serially diluted. The mice 
were treated intragastrically with $\beta$-sitosterol $\left(50 \mathrm{mg} \cdot \mathrm{kg}^{-1} \cdot \mathrm{d}^{-1}\right.$, $200 \mathrm{mg} \cdot \mathrm{kg}^{-1} \cdot \mathrm{d}^{-1}$ ) or PBS (vehicle group) 2 days prior to viral challenge. The mice were anesthetized (5\% isoflurane inhalation) and challenged intranasally with $5 \mathrm{LD}_{50}$ of mouse-adapted H1N1 virus.

\section{Cell culture and viral infection}

Human alveolar epithelial A549 cells and 293T human embryonic kidney cells were grown in Dulbecco's modified Eagle's medium (DMEM/F12, 1:1 mixture) (Gibco) supplemented with 10\% fetal bovine serum (FBS) (Gibco) in a humidified incubator at $37^{\circ} \mathrm{C}$ and $5 \% \mathrm{CO}_{2}$.

For the viral infection, A549 cells $\left(5 \times 10^{6}\right.$ cells $\left./ \mathrm{mL}\right)$ grown in 6well tissue culture plates (Guangzhou Jet Bio-Filtration Co., Ltd, TCP-010-006) were inoculated with $A / P R / 8 / 34$ (H1N1) in serumfree DMEM/F12 medium at an indicated multiplicity of infection (MOI). After $2 \mathrm{~h}$ absorption, the inoculum was discarded and replaced with fresh serum-free DMEM/F12 medium containing diluted compounds.

Antibodies and recombinant protein

The following primary antibodies were used in the current study: anti-RIG-I, anti-NF-KB p65, anti-phospho-NF-KB p65 (Ser ${ }^{536}$ ), anti-p38 MAPK, anti-phospho-p38 MAPK $\left(\mathrm{Thr}^{180} / \mathrm{Tyr}^{182}\right)$, anti-STAT1, antiphospho-STAT1 (Tyr $\left.{ }^{701}\right)$, anti-STAT2, anti-phospho-STAT2 $\left(\mathrm{Tyr}^{690}\right)$, anti-JAK1, anti-phospho-JAK1(Tyr $\left.{ }^{1034 / 1035}\right)$, anti-phospho-p44/p42 MAPK (ERK1/2) $\left(\mathrm{Thr}^{202} / \mathrm{Tyr}^{204}\right)$, anti-p44/p42 MAPK (ERK1/2), antiphospho-SAPK/JNK MAPK (Thr ${ }^{183} / \mathrm{Tyr}^{185}$ ), anti-SAPK/JNK MAPK, antiCOX2, and anti-GAPDH (Cell Signaling Technology). Anti-PARP and anti-caspase3 (active form) antibodies were purchased from Gentex. Recombinant human TNF-a, IFN- $\beta$, and IFN- $\lambda 1$ (IL-29) were purchased from Peprotech.

Protein preparation and immunoblot analysis

Excised lungs and cells were lysed using ice-cold RIPA buffer $(25 \mathrm{mM}$ Tris. $\mathrm{HCl} \mathrm{pH}$ 7.6, $150 \mathrm{mM} \mathrm{NaCl}, 1 \% \mathrm{NP}-40,1 \%$ sodium deoxycholate, and $0.1 \%$ SDS) supplemented with protease inhibitors (Sigma). The crude lysates were centrifuged at $14,000 \mathrm{rpm}(13,000 \times g)$ for $15 \mathrm{~min}$ at $4{ }^{\circ} \mathrm{C}$, and the supernatant was collected. Equal amounts of cell or tissue extracts were loaded onto $10 \%$ SDS-polyacrylamide gels for separation. Then, proteins were transferred to $0.2 \mu \mathrm{m}$ PVDF membranes (Bio-Rad), which allowed subsequent probing with primary antibodies. After overnight incubation at $4{ }^{\circ} \mathrm{C}$, the membranes were washed with $0.1 \%$ TBST (TBS/0.1\% Tween 20) and incubated with corresponding horseradish peroxidase (HRP)conjugated secondary antibodies (Multisciences). The signals were visualized using enhanced chemiluminescence $(E C L)$ reagents (Perkin-Elmer). Quantification of the relative band intensities was performed using ImageJ software version 1.43.

pppRNA generation, RNA isolation, and real-time RT-PCR Viral RNA (5'-triphosphate RNA, 5'ppp-RNA) and cellular RNA were generated as previously described [46]. Briefly, total RNA was isolated from A549 lung epithelial cells infected with A/PR/8/34(H1N1) for $24 \mathrm{~h}$ (viral RNA) and uninfected A549 lung epithelial cells (cellular RNA) using TRIzol reagent (Takara, USA). Then, the 5 '-phosphate group was dephosphorylated by treatment with calf-intestinal alkaline phosphatase (CIAP) (Takara). A549 lung epithelial cells were transfected with the indicated RNA using LP2000 (Thermo, USA).

For qPCR, total RNA $(1 \mu \mathrm{g})$ was reverse transcribed into CDNA and subjected to real-time quantitative $P C R$ with gene-specific primers and probes on an ABI7500 real-time PCR system. Relative gene expression was calculated using the $2^{-\Delta \Delta c t}$ method [47]. The specific primer and probe sets are shown in Supplementary Table S1.

Small interfering RNA (siRNA), plasmid transfection, and reporter gene assays

Transient transfection of plasmids into cells, including an ISRE luciferase reporter plasmid (Beyotime) and a Flag-RIG-I overexpression plasmid (Geneppl), was performed by using Lipofectamine 2000 (Invitrogen). After ISRE luciferase reporter plasmid $(0.5 \mu \mathrm{g})$ and Flag-RIG-I $(0.5 \mu \mathrm{g})$ overexpression plasmid were transfected into A549 cells for $6 \mathrm{~h}$, the transfected cells were stimulated with IFNs or IAV $(\mathrm{MOI}=0.1)$. In the other experiment, HEK293 cells stably co-transfected with pNF-KB-TATA-F-LUCI and pQCXIP-eGFP plasmid were stimulated with TNF-a $(20 \mathrm{ng} / \mathrm{mL})$ or IAV for the indicated times. Firefly luciferase activity was assayed using the luciferase reporter system (Promega, USA) and normalized to renilla luciferase activity or the levels of GFP expression.

RIG-I-specific siRNAs (RIG-I \#1 siRNA and, RIG-I \#2 siRNA) were purchased from Guangzhou RiboBio Co., Ltd. and transfected into cells with Lipofectamine 2000 according to the manufacturer's instructions.

\section{Histology and immunohistology}

Lung tissue was excised, fixed in $10 \%$ formalin and embedded in paraffin using routine procedures. Tissue sections $(4 \mu \mathrm{m})$ were stained with hematoxylin-eosin for histological examination. For immunohistochemical staining, the sections were deparaffinized with xylene and rehydrated in a graded alcohol series. Endogenous peroxidase was blocked with $3 \%$ hydrogen peroxide $\left(\mathrm{H}_{2} \mathrm{O}_{2}\right)$ in methanol for $20 \mathrm{~min}$ at room temperature and antigen retrieval was performed in $0.01 \mathrm{mM}$ citrate buffer $(\mathrm{pH} \mathrm{6.0)}$. Afterward, the sections were blocked with $5 \%$ normal serum and incubated with primary antibody at $4{ }^{\circ} \mathrm{C}$ overnight. The sections were then incubated for $1 \mathrm{~h}$ in HRP-labeled secondary antibody solution and then visualized using a DAB reagent kit (Maixin, China). The sections were counterstained with Mayer's hematoxylin for 2 min before mounting.

Apoptosis detection by annexin V and flow cytometry

Cells collected from both suspension and adherent were washed twice with cold PBS, and subsequently resuspended in $1 \times$ annexin binding buffer (Bioscience, USA) at a concentration of $2 \times 10^{6}$ cells $/ \mathrm{mL}$. One hundred microliters of cell suspension was stained with $5 \mu \mathrm{L}$ of Annexin V-FITC and $5 \mu \mathrm{L}$ of propidium iodide (PI) for $15 \mathrm{~min}$ at room temperature in the dark. The cells were analyzed using a NovoCyte flow cytometer within $4 \mathrm{~h}$.

Bronchoalveolar lavage and flow cytometry

Mice were euthanized intraperitoneally (i.p.) with an overdose of sodium pentobarbital at the indicated time point. The trachea was cannulated via ventral middle incision. The lungs were lavaged three times with $600 \mu \mathrm{L}$ of sterile saline. Bronchoalveolar lavage fluid (BALF) was centrifuged at $300 \times g$ for $10 \mathrm{~min}$ at $4{ }^{\circ} \mathrm{C}$ and the supernatants were collected and stored at $-80^{\circ} \mathrm{C}$ for biochemical analysis. The BALF pellets were resuspended in PBS with $0.5 \%$ BSA and stained with fluorochrome-conjugated monoclonal antibodies (mAbs) (Bioscience, USA) that bound to surface molecules for $20 \mathrm{~min}$ at $4{ }^{\circ} \mathrm{C}$. All samples were analyzed on a NovoCyte flow cytometer.

Statistical analysis

All data are presented as the mean \pm SEM. Statistical analysis was performed using SPSS software version 18.0. One-way ANOVA followed by the Student-Newman-Keuls (SNK) test was carried out to assess differences between the study groups, and $P$ values less than 0.05 were considered significant.

\section{RESULTS}

Quantitative analysis of $\beta$-sitosterol in five medicinal materials Medicinal plants including L. japonica, C. morifolium, T. mongolicum, F. suspense, and I. indigotica are traditionally used for heatclearing and detoxification. We hypothesized that $\beta$-sitosterol is the common substance in these medicinal plants that mediates their pharmacological actions against respiratory diseases, such as 
influenza. First, we quantified the content of $\beta$-sitosterol in these plants. As shown in Table 1, $\beta$-sitosterol was detected in all samples at concentrations ranging from 0.51 to $2.23 \mathrm{mg} / \mathrm{g}$.

$\beta$-Sitosterol treatment inhibits the activation of the cellular signaling pathway in IAV-infected cells

To clarify whether $\beta$-sitosterol possesses antiviral activity for the treatment of IAV infection, cytopathic effect (CPE) inhibition assays and plaque reduction assays were performed to investigate the antiviral effects of $\beta$-sitosterol. As shown in Supplementary Table S2, $\beta$-sitosterol showed no activity against A/GZ/GIRD07/ 09(H1N1)， A/PR/8/34(H1N1)，A/HK/8/68(H3N2), A/HK/Y280/97 (H9N2), or B/Lee/1940 (FluB). These findings were further confirmed by plaque reduction assays (Supplementary Fig. S1). The activation of multiple cellular signaling events has been implicated in the molecular pathogenesis of IAV infection [48]. To identify the pharmacological effects exerted by $\beta$-sitosterol during IAV infection, we assessed the impact of $\beta$-sitosterol on the activation of cellular signaling pathway in cells infected with IAV. HEK293 cells in which an NF-KB-luc reporter was stably expressed were stimulated with either TNF-a $(20 \mathrm{ng} / \mathrm{mL}$ ) (Fig. 1a) or A/PR/8/ 34 (H1N1) (Fig. 1b), and then incubated with $\beta$-sitosterol for $24 \mathrm{~h}$. We observed that HEK293 cells stimulated with TNF-a or A/PR/8/ 34 (H1N1) exhibited robust NF-kB activation, on which $\beta$-sitosterol treatment had a dose-dependent suppressive effect (Fig. 1a, b). Furthermore, to test whether $\beta$-sitosterol possesses other pharmacological properties, we assessed the activation of signaling pathways in IAV-infected A549 cells in the presence or absence of $\beta$-sitosterol by immunoblotting. NF-KB and MAPK (P38, ERK1/2, and JNK/SPAK) signaling was activated by IAV infection (Fig. 1C). As expected, $\beta$-sitosterol inhibited the IAV-induced p38 MAPK activation and p65 phosphorylation, which is consistent with the data gathered using the NF-KB-luc reporter cell line. However, $\beta$ sitosterol had no inhibitory effect on the ERK1/2 or JNK MAPK pathway. Together, these data demonstrate that $\beta$-sitosterol has the potential to inhibit the activation of NF-KB and p38 MAPK signaling in response to IAV infection.

$\beta$-Sitosterol treatment decreases the expression of IAV-induced proinflammatory mediators

Both the NF-KB and p38 MAPK signaling cascades have been implicated as major contributors to hypercytokinemia during human HPAIV H5N1 infection [49, 50]. Therefore, we next investigated the effect of $\beta$-sitosterol on the expression of proinflammatory mediators in IAV-infected cells. A549 cells were infected with the $\mathrm{PR} 8 / \mathrm{H} 1 \mathrm{~N} 1$ virus $(\mathrm{MOI}=0.1)$ in the presence of increasing concentrations of $\beta$-sitosterol $(150-450 \mu \mathrm{g} / \mathrm{mL})$ for $24 \mathrm{~h}$. Subsequently, the transcript levels of proinflammatory mediators were measured by QPCR. Our data showed that the gene expression of an array of cytokines and chemokines, including IL-6, TNF-a, IP-10, IL-8, MCP-1, MIP-1 $\beta$, and Rantes, was elevated dramatically following IAV infection, and that this elevation was attenuated by $\beta$-sitosterol treatment (Fig. 2a). The kinetics of IAVinduced proinflammatory mediator release showed that the protein levels of these proinflammatory mediators (including

\begin{tabular}{|ll|}
\hline $\begin{array}{l}\text { Table 1. } \\
(n=3) .\end{array}$ & Contents of $\beta$-sitosterol in five kinds of medical materials \\
\hline Samples & $0.51(0.051 \%)$ \\
\hline L. japonica & $1.34(0.134 \%)$ \\
C. morifolium & $2.23(0.223 \%)$ \\
T. mongolicum & $1.92(0.192 \%)$ \\
F. suspense & $1.54(0.154 \%)$ \\
I. indigotica & \\
\hline
\end{tabular}

IL-6, TNF-a, IL-8, IP-10, Rantes, and MCP-1) reached their expression peak at $24 \mathrm{~h}$ after viral infection (Fig. 2b), and that the increases in the levels of these mediators were reversed by $\beta$-sitosterol treatment (Fig. 2c). The production of cyclooxygenase2 (COX-2) and its derivative prostaglandin E2 (PGE2), has been shown to occur via NF-KB and p38 MAPK signaling and play a pathogenic role during IAV infection [51, 52]. Indeed, increasing the expression of IAV-induced COX-2 at both the mRNA and protein levels at $24 \mathrm{~h}$ p.i., while treatment with $\beta$-sitosterol profoundly reduced COX-2 production (Fig. 2d, e). Furthermore, we measured the effect of $\beta$-sitosterol on the IAV-induced expression of IAV-induced COX-2 and carried out ELISA to quantify COX-2-derived PGE2 in the culture supernatants. As expected, $\beta$-sitosterol treatment of IAV-infected cells led to a significant dose-dependent reduction in PGE2 levels (Fig. 2f). These results indicate that $\beta$-sitosterol treatment decreases the expression of IAV-induced proinflammatory mediators through the inactivation of the NF-KB and p38 MAPK signaling pathways.

$\beta$-Sitosterol treatment suppresses the IAV-mediated induction of interferon expression and signal transduction by targeting RIG-I In response to IAV infection, transcription factors including NF-KB, ATF2/c-jun, and IRF3/7 bind cooperatively to the promoter regions of IFN genes, which are secreted to establish an antiviral state, to initiate their expression [10]. The activation of p38, which mediates the activation of its downstream target ATF2, is a prerequisite for optimal IFN- $\beta$ induction [12]. Since $\beta$-sitosterol inhibits the IAV-induced activation of $\mathrm{p} 38$, we hypothesized that $\beta$-sitosterol treatment might reduce the expression of IFNs. To test this hypothesis, culture supernatants from IAV-infected A549 cells treated with or without $\beta$-sitosterol were collected at $24 \mathrm{~h}$ p.i. and transferred to uninfected A549 cells. After $15 \mathrm{~min}$ of incubation, we assessed IFN levels in the culture supernatant by monitoring the phosphorylation and downstream signaling of IFNs by immunoblot analysis. As shown in Fig. 3a, supernatants from infected A549 cells stimulated the phosphorylation of STAT1 ${ }^{\text {Tyr701 }}$ and STAT2 ${ }^{\text {Tyr690, }}$, while supernatants from donor cells treated with $\beta$-sitosterol attenuated the phosphorylation of STAT1 ${ }^{\text {Tyr701 }}$. Our results indicated that the suppression of STAT1 ${ }^{\text {Tyr701 }}$ phosphorylation by $\beta$-sitosterol was associated with reduced IFNs production. To further confirm that $\beta$-sitosterol inhibits the IAV-induced expression of IFNs, IFN concentrations in supernatants collected at $24 \mathrm{~h}$ p.i. were measured using Luminex. As demonstrated in Fig. 3b, the IAV-induced elevation of IFNs, including type I IFN (IFN$\beta)$, type II IFN (IFN- $\gamma)$, and type III IFN (IFN- $\lambda 1$ ), was significantly decreased in the supernatants of $\beta$-sitosterol-treated cells.

These observations led us to ask whether $\beta$-sitosterol directly affects the IFN signaling transduction pathway. To address this question, we tested whether signal transduction induced by exogenous IFN- $\beta$ is altered by $\beta$-sitosterol treatment. Then, we pretreated IAV-infected A549 cells with $\beta$-sitosterol for $4 \mathrm{~h}$ before stimulating them with IFN- $\beta$ for $15 \mathrm{~min}$. The phosphorylation of $\mathrm{STAT}^{\text {Tyr701 }}$, but not STAT2, was markedly inhibited by $\beta$-sitosterol treatment (Fig. $3 \mathrm{c}$ ). However, at later time points ( $8 \mathrm{~h}$ p.i.), the IFN$\beta$-mediated phosphorylation of STAT1 Tyr701 was reduced in IAVinfected A549 cells regardless of whether they were pretreated with $\beta$-sitosterol or not (Fig. 3d).

Our data demonstrated that $\beta$-sitosterol reduced IFN production through the inhibition of NF-KB and p38 MAP kinase and that it blocks IFN-mediated signal transduction. We next sought to elucidate the mechanism by which $\beta$-sitosterol disrupts IFN production and signaling. The intracellular PRR RIG-I senses IAV $5^{\prime}$ ppp-RNA, resulting in the activation of NF-KB and p38 MAP kinase which preferentially promote the initiation of IFN transcription [53]. It is worth mentioning that RIG-I, an interferon-stimulated gene (ISG), has been reported to augment STAT1 activation and inhibit leukemia cell proliferation [54]. Thus, it is reasonable to speculate that cross-talk between the RIG-I and 

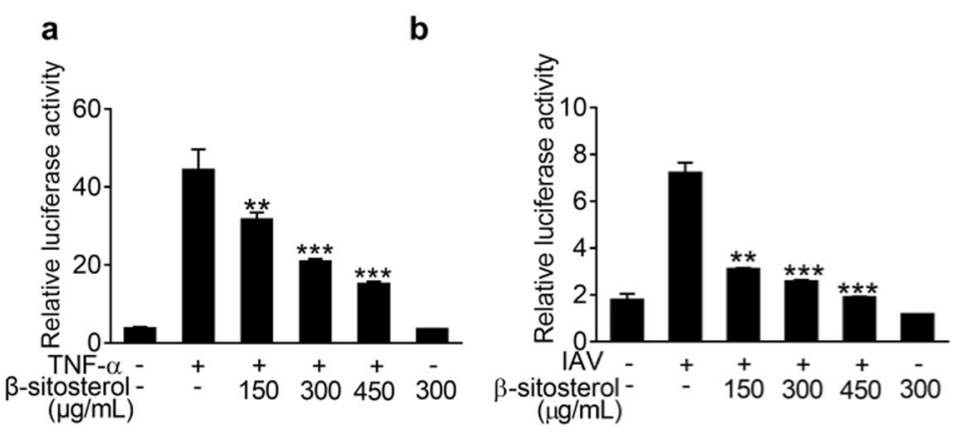

c
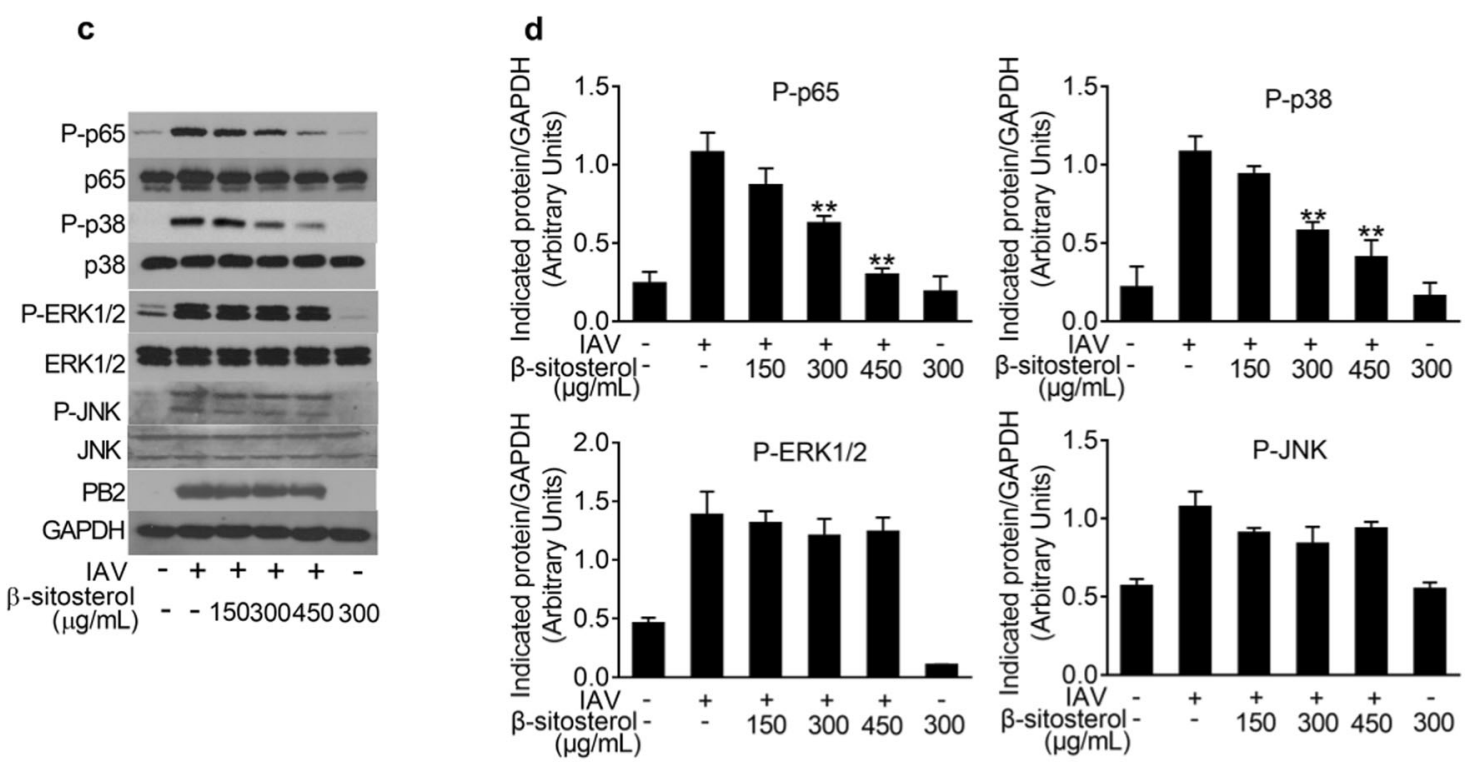

Fig. 1 Effect of $\boldsymbol{\beta}$-sitosterol on NF-KB and MAPK signaling in IAV-infected cells. a, b HEK293 cells (a stable NF- $\kappa B$ luciferase reporter cell line) were stimulated with TNF- $\alpha(20 \mathrm{ng} / \mathrm{mL})(\mathbf{a})$ and influenza $\mathrm{A} / \mathrm{PR} / 8 / 34(\mathrm{H} 1 \mathrm{~N} 1)$ virus $(\mathrm{MOI}=0.1)(\mathbf{b})$ in the presence or absence of the indicated concentrations of $\beta$-sitosterol for $24 \mathrm{~h}$. The cells were lysed and then assayed for luciferase activity. c Human lung epithelial cells (A549) were inoculated with influenza $\mathrm{A} / \mathrm{PR} / 8 / 34(\mathrm{H} 1 \mathrm{~N} 1)$ virus $(\mathrm{MOI}=0.1)$. After $2 \mathrm{~h}$, the inoculum was removed and replaced with fresh FCS-free media in the presence or absence of the indicated concentrations of $\beta$-sitosterol for an additional $24 \mathrm{~h}$. Then, the total cell extracts were subjected to immunoblotting with antibodies as indicated. The blots were reprobed with an antibody against GAPDH as the internal control. Representative results from at least three independent experiments are shown. $\mathbf{d}$ The band intensities of P-p65, P-p38, P-ERK1/2, and P-JNK were semiquantified using imageJ (normalized to the loading control GAPDH). The data are presented as the mean \pm SEM $(n=3-5)$. ${ }^{* *} P<0.01$, *** $P<0.001$ versus the group treated with TNF- $\alpha$ or IAV.

IFN signaling pathways is affected by $\beta$-sitosterol. To confirm this assumption, we investigated the effect of $\beta$-sitosterol on the IAVinduced expression of RIG-I. Our results show that $\beta$-sitosterol decreased the induction of RIG-I in infected A549 cells (Fig. 3e, f). Furthermore, cells transfected with the Flag-RIG-I overexpression plasmid transfection were found to have elevated p-STAT1 levels, which were diminished by $\beta$-sitosterol treatment (Fig. 3g). The tyrosine kinases JAKs are well recognized to be involved in the activation of STAT1. Therefore, it is possible that $\beta$-sitosterol affected STAT1 activation by inhibiting JAKs. Interestingly, we found that $\mathrm{A} 549$ cells pretreated with $\beta$-sitosterol for $12 \mathrm{~h}$ prior to IFN- $\beta(20 \mathrm{ng} / \mathrm{mL})$ stimulation did not exhibit decreased IFN- $\beta$ mediated activation of JAK1, STAT1, and STAT2 levels (Fig. 3h). Together, these data indicate that $\beta$-sitosterol can exert an inhibitory effect on RIG-I, which leads to decreased IAV-induced IFN production and IFN- $\beta$ signal transduction.

$\beta$-Sitosterol treatment attenuates the IFN-mediated amplification of the proinflammatory response during IAV infection via the inhibition of RIG-I

It is widely recognized that IFN signaling plays a vital role in host antiviral immunity [55]. Furthermore, IFNs possess immunomodulatory activities on the induction of both chemokines and cytokines and on the recruitment of various immune cells [56]. To examine the effect of RIG-I inhibition by $\beta$-sitosterol on the transcription of IFN signaling-related molecules, we analyzed IAV-mediated IFN-stimulated response element (ISRE) activation with an assay that utilized a transient ISRE reporter plasmid. The results presented in Fig. 4a show that IAV-mediated ISRE-dependent transcription was significantly inhibited by $\beta$ sitosterol treatment. RIG-I knockdown in IAV-infected cells by specific siRNAs in IAV-infected cells was confirmed to significantly inhibit the IAV-mediated ISRE transcriptional activity (Fig. 4b, c). To further determine the effects of $\beta$-sitosterol on IFN-induced proinflammatory responses during IAV infection, ISRE reporter plasmid-transfected cells were stimulated with IFN- $\beta(500 \mathrm{ng} / \mathrm{mL})$ $4 \mathrm{~h}$ prior to IAV infection. Prestimulation with IFN- $\beta$ led to much higher ISRE activity than IAV infection alone (Fig. 4d). Similarly, IFN- $\beta$ stimulation following IAV infection also resulted in increased ISRE activity, but to a lesser extent than what was seen after IFN- $\beta$ prestimulation (Fig. 4d). This indicates that IFN- $\beta$ signaling contributes to the amplification of ISRE activity during IAV infection. Nevertheless, this increase in ISRE activity was diminished in a dose-dependent manner by $\beta$-sitosterol treatment 

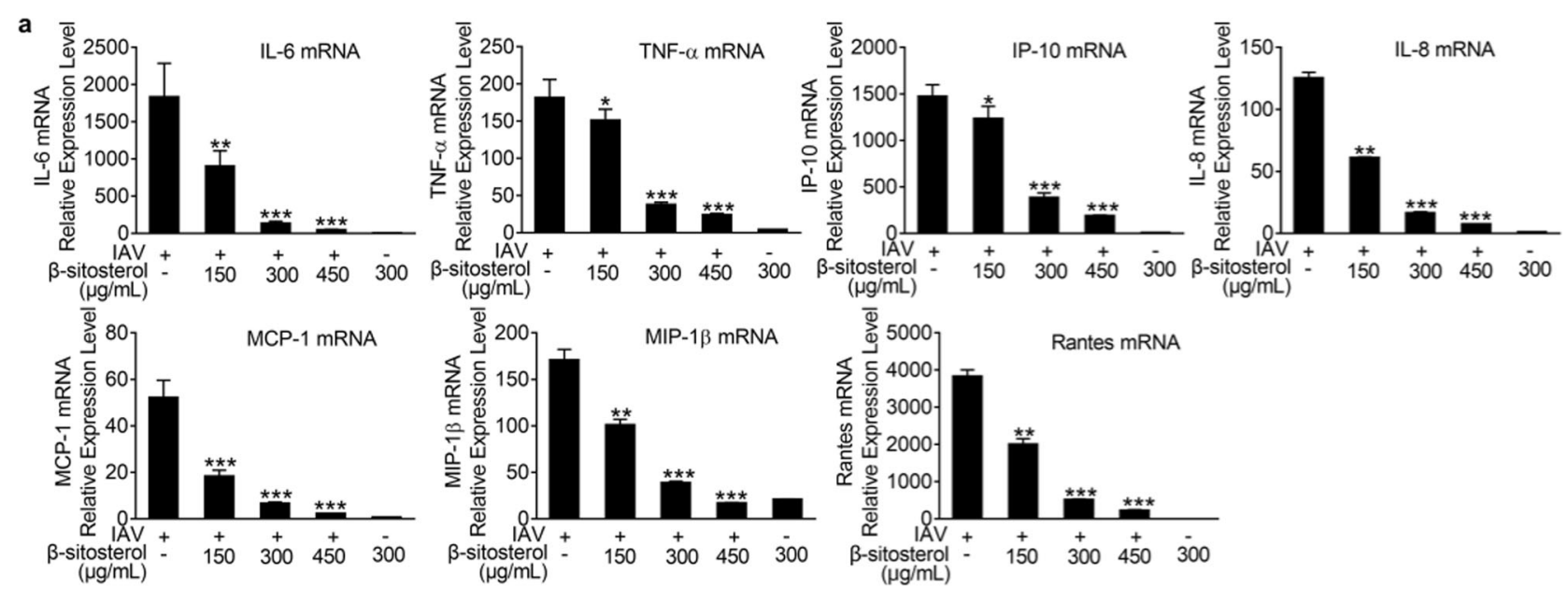

b
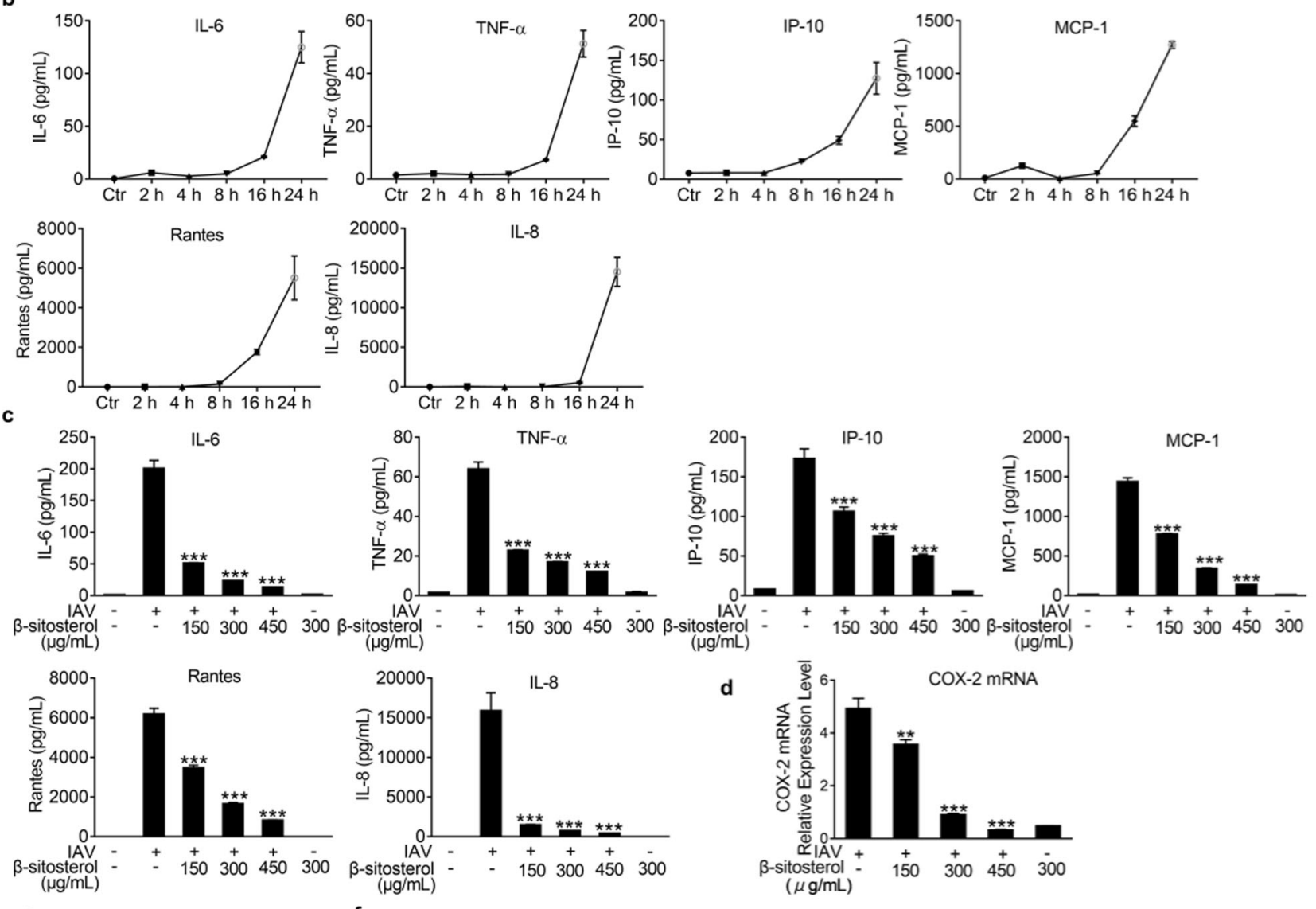

e

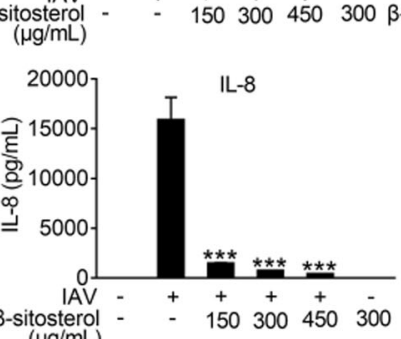

( $\mu \mathrm{g} / \mathrm{mL}$ )

d

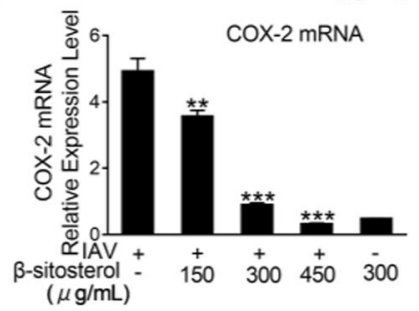

f
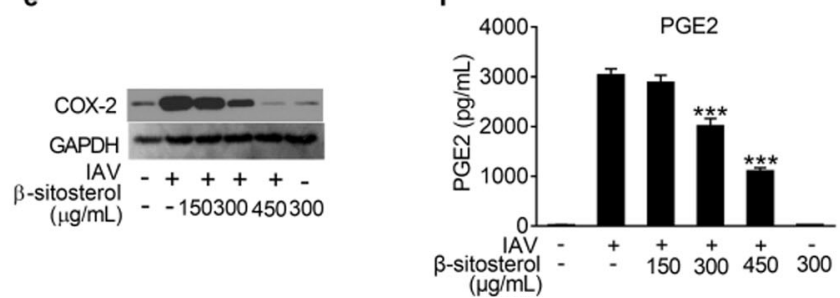

Fig. 2 Effect of $\boldsymbol{\beta}$-sitosterol on the IAV-induced expression of proinflammatory mediators. After allowing $2 \mathrm{~h}$ for IAV absorption, IAV-infected A549 cells were treated with or without the indicated concentrations of $\beta$-sitosterol for $24 \mathrm{~h}$. a The gene expression levels of proinflammatory cytokines and chemokines in IAV-infected A549 cells treated with or without $\beta$-sitosterol were determined using quantitative real-time PCR at $24 \mathrm{~h}$ p.i. b The kinetics of proinflammatory mediators in the culture supernatants of IAV-infected cells for $2,4,8,16$, and $24 \mathrm{~h}$ were detected by a multiplex Luminex assay. c The effect of $\beta$-sitosterol on the secretion of proinflammatory cytokines and chemokines in the supernatant of IAVinfected A549 cells. At $24 \mathrm{~h}$ p.i., cell culture supernatants were collected for use in a multiplex Luminex assay. d, e Effect of $\beta$-sitosterol on the expression of cyclooxygenase-2 (COX-2) in IAV-infected A549 cells. The gene expression levels of COX-2 were assayed by real-time PCR (d). Immunoblot analysis was performed to evaluate the protein expression of COX-2. GAPDH was used as the internal control (e). $\mathbf{f}$ Quantification of PGE2 in the culture supernatants using ELISA. ${ }^{*} P<0.05,{ }^{* *} P<0.01,{ }^{* *} P<0.001$ versus the IAV control group. 
a

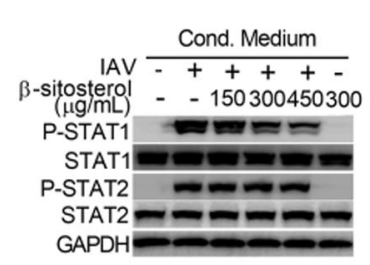

c

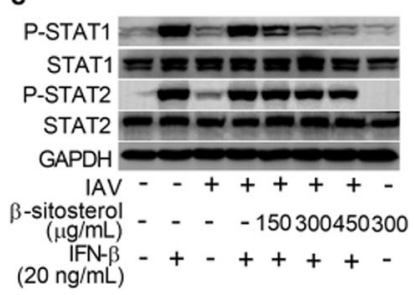

f

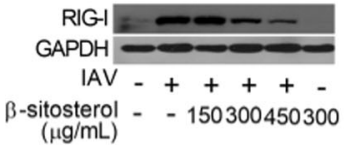

b
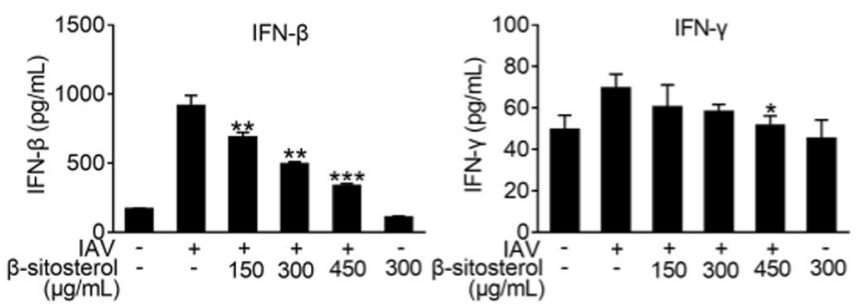

$(\mu \mathrm{g} / \mathrm{mL})$

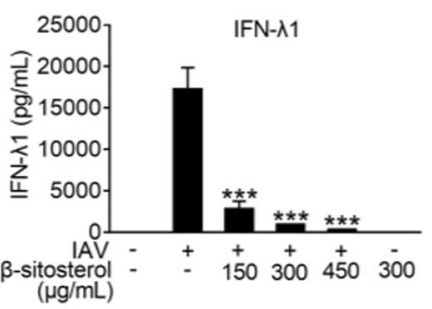

d
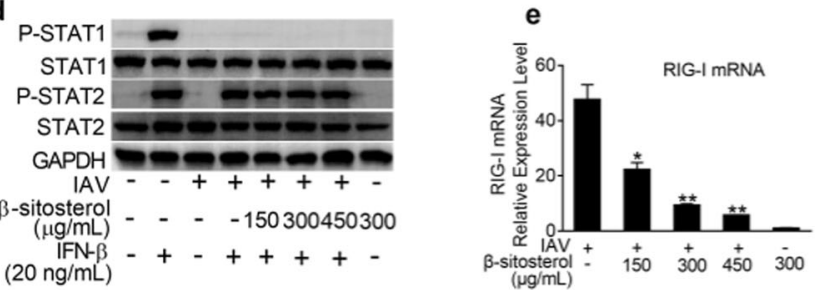

g

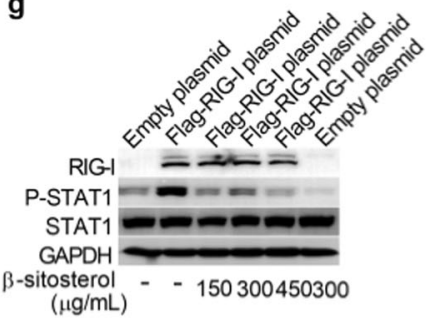

h

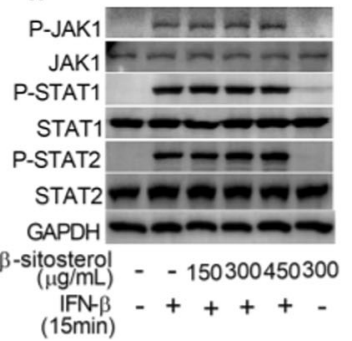

Fig. 3 Effect of $\boldsymbol{\beta}$-sitosterol treatment on IAV-induced IFN production and IFN signal transduction. a After $24 \mathrm{~h}$, IAV-infected cells with or without the indicated concentration of $\beta$-sitosterol treatment were harvested, and the supernatants were transferred to uninfected cells. After $15 \mathrm{~min}$ of incubation, the cells were lysed, and the expression of phosphorylated STAT1 and STAT2 was analyzed by immunoblotting. Equal loading of protein was verified by immunoblotting for GAPDH. b IFNs (IFN- $\beta$, IFN- $\gamma$, and IFN- $\lambda 1$ ) secretion into the culture media was measured at $24 \mathrm{~h}$ p.i. using a multiplex Luminex assay. c, d After allowing $2 \mathrm{~h}$ for IAV absorption, A549 cells were incubated with the indicated concentration of $\beta$-sitosterol for $4 \mathrm{~h}$ (c) or $8 \mathrm{~h}$ (d). Then, the cells were stimulated for an additional $15 \mathrm{~min}$ with human IFN- $\beta$ ( $20 \mathrm{ng} / \mathrm{mL}$ ). The cells were lysed, and total extracts were processed for immunoblotting. e, f Effect of $\beta$-sitosterol on the expression of RIG-I. RIG-I mRNA expression levels were assayed by quantitative real-time PCR (e). RIG-I protein levels were assessed by Western blotting (f). $\mathbf{g}$ A549 cells were transfected with a Flag-RIG-I overexpression plasmid, and then treated with $\beta$-sitosterol. After $24 \mathrm{~h}$, the cell lysates were collected for immunoblotting. h A549 cells were pretreated with $\beta$-sitosterol for $12 \mathrm{~h}$, stimulated with IFN- $\beta$ ( $20 \mathrm{ng} / \mathrm{mL})$ for $15 \mathrm{~min}$, and immunoblotted for the indicated proteins. ${ }^{*} P<0.05,{ }^{*} P<0.01,{ }^{* *} P<0.001$ versus the IAV control group.

(Fig. 4d). We next assessed the effects of $\beta$-sitosterol on the expression of proinflammatory genes in IAV-infected cells pretreated with or without IFN- $\beta$. Consistent with the previously observed increase in ISRE activity, the MRNA and protein levels of cytokines and chemokines, including IL-6, IP-10, TNF-a, IL-8, MCP-1 and GM-CSF, were robustly increased in IAV-infected cells after stimulation with IFN- $\beta$ (Fig. 4e, f). A similar cytokine and chemokine expression pattern was observed in response to stimulation with IFN- $\lambda 1$ (data not shown), which signals through the JAK/STAT pathway leading to ISRE activation. As expected, the elevation in cytokine and chemokine levels induced by IFN stimulation was decreased by $\beta$-sitosterol treatment (Fig. $4 \mathrm{e}$, f). To understand whether the attenuation of the amplified proinflammatory response in IFN- $\beta$ pretreated cells was solely due to a reduction in IFN- $\beta$ levels, cells with IFN- $\beta$ prestimulated for $4 \mathrm{~h}$ were treated with an IFN- $\beta$ neutralizing antibody $(2.5 \mu \mathrm{g} / \mathrm{mL})$ prior to virus infection. However, we observed that the amplification effects of proinflammatory mediators (IL-6 and IP-10) in cells prestimulated with IFN- $\beta$ were not abrogated by IFN- $\beta$ neutralizing antibody treatment (Fig. 4g). This indicates that cells prestimulated with IFN- $\beta$ become sensitized and thereby amplify proinflammatory responses.

To understand whether the observed inhibitory effect of $\beta$ sitosterol was due to STAT1 inhibition, we measured the phosphorylation of STAT1 ${ }^{\text {Tyr701 }}$ in A549 cells stimulated with
IFN- $\beta(500 \mathrm{ng} / \mathrm{mL})$. STAT1 was significantly activated in cells pretreated with IFN- $\beta$ (lane 4), but not in cells infected with IAV prior to IFN- $\beta$ stimulation (lane 8). Treatment with $\beta$-sitosterol abrogated STAT1 activation in a dose-dependent manner (lanes $5-7)$ (Fig. 4h), indicating that the inhibitory effect of $\beta$-sitosterol on STAT1 reduced the IFN-mediated amplification of cytokine and chemokine expression. Notably, pretreatment with IFN- $\beta$ significantly increased the IAV-triggered expression of RIG-I in A549 cells, which was inhibited by $\beta$-sitosterol treatment (Fig. $4 \mathrm{i}, \mathrm{j}$ ). Together, these data demonstrate that $\beta$-sitosterol blocks the IAV-induced amplification of the proinflammatory response in IFN- $\beta$-activated A549 cells, which is due to inhibition of RIG-I levels by $\beta$-sitosterol, leading to the inactivation of STAT1, and thereby diminishes the transcriptional activity of interferon-stimulated gene factor 3 (ISGF3).

$\beta$-Sitosterol treatment suppresses RIG-I-induced apoptosis and inflammation

In addition to playing a role in IFN induction, RIG-I signaling has been demonstrated to be involved in apoptosis [57], which is implicated in IAV-induced lung epithelial cell damage and injury. Therefore, we investigated whether $\beta$-sitosterol affects RIG-Imediated apoptosis using intracellular viral RNA (vRNA, 5'pppRNA) stimulation. Stimulation with cellular RNA (cRNA) or vRNA and treatment with calfintestine alkaline phosphatase (CIAP) to 

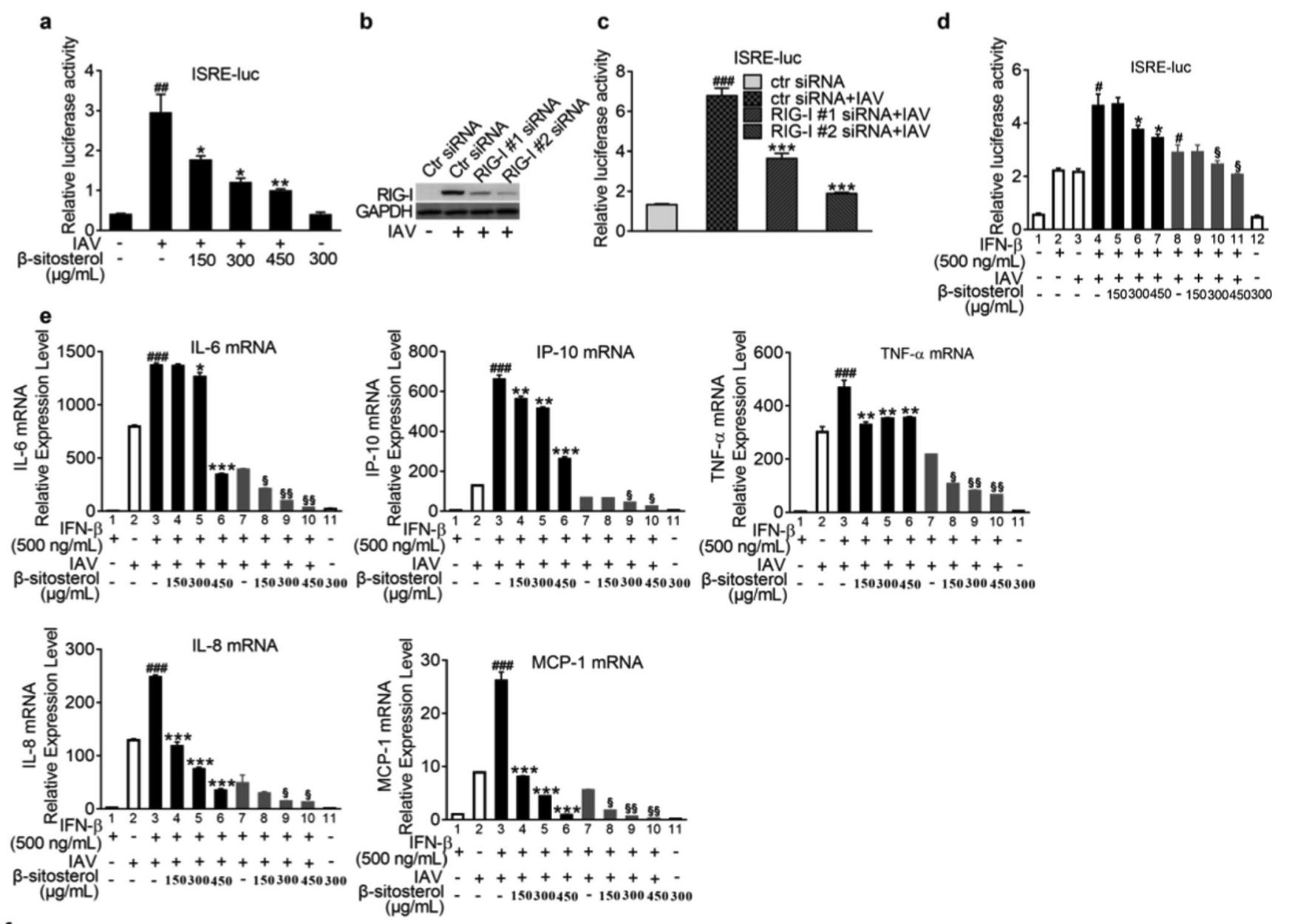

f
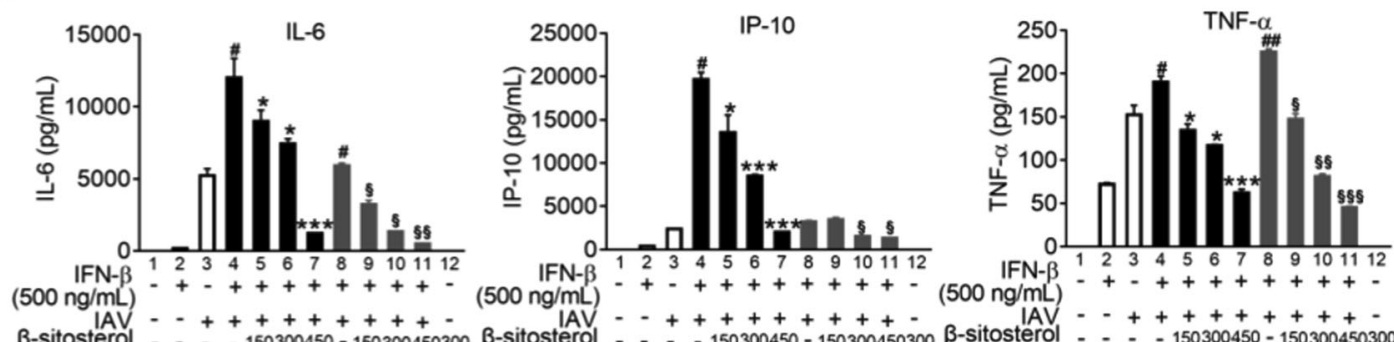

$(500 \mathrm{ng} / \mathrm{mL})$

$\beta$-sitosterol - + + + + + + + + + + $(\mu \mathrm{g} / \mathrm{mL})$
-

$(\mu \mathrm{g} / \mathrm{mL})$

$\mathrm{ng} / \mathrm{mL}$ )
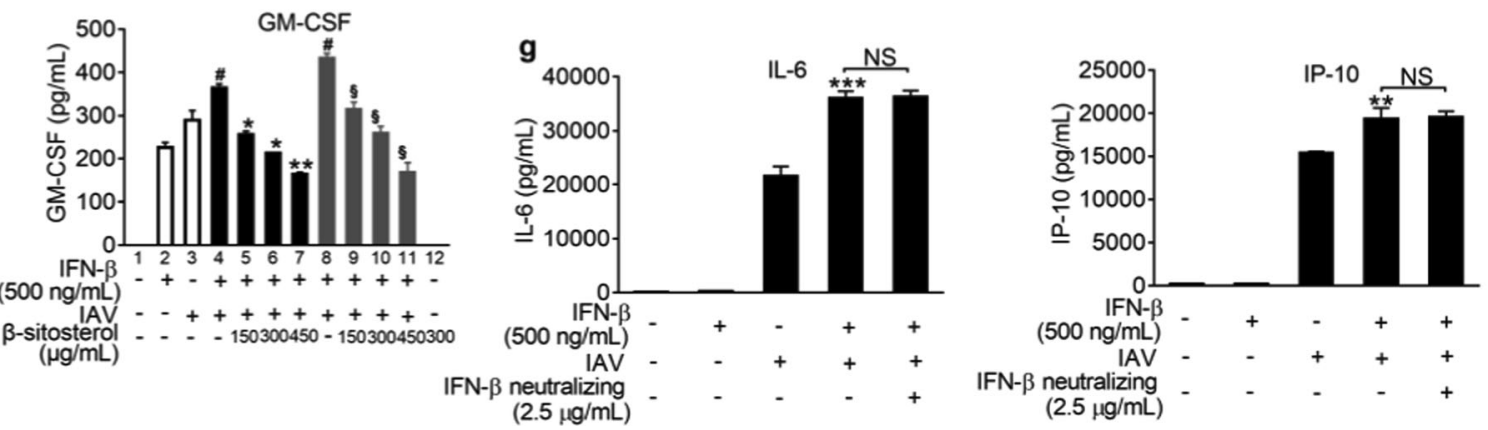

Fig. 4 (continued)

dephosphorylate $5^{\prime}$-triphosphate did not induce apoptosis, excluding the possibility that CRNA or the non-phosphate at the $5^{\prime}$ end of RNA has a pro-apoptotic effect (Fig. 5a). Strikingly, the apoptosis of vRNA-transfected cells was reduced by $\beta$-sitosterol treatment (Fig. 5a). We confirmed the anti-apoptotic effect of $\beta$ sitosterol by measuring the active caspase- 3 and its substrate PARP, observing that these products were found in cells transfected with vRNA but not in those treated with $\beta$-sitosterol 
h

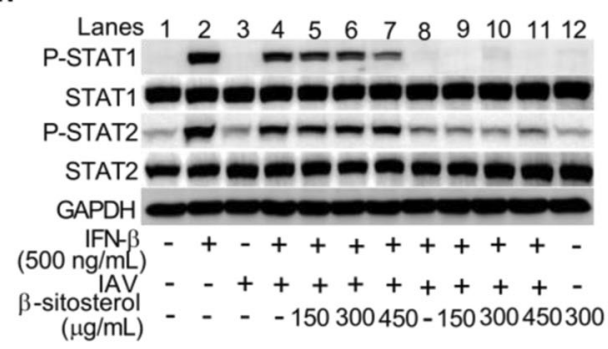

j

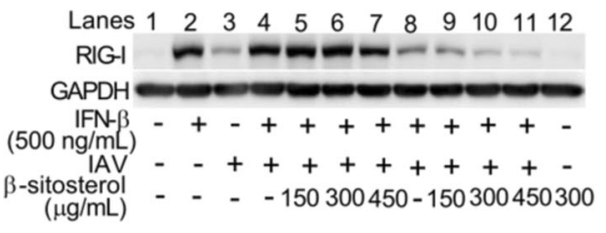

i

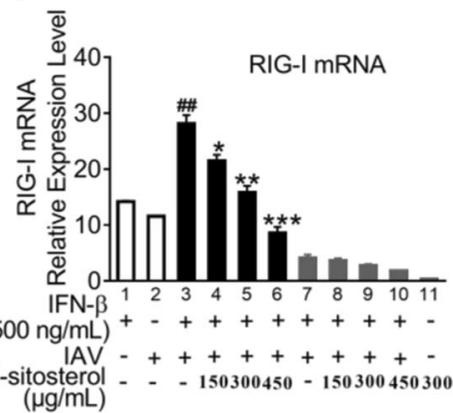

RIG-I

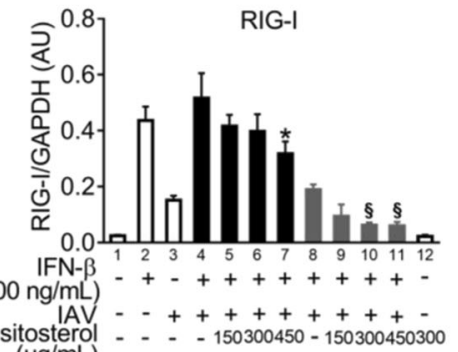

$(\mu \mathrm{g} / \mathrm{mL})$

Fig. 4 Effect of $\boldsymbol{\beta}$-sitosterol on the IFN- $\boldsymbol{\beta}$-mediated amplification of IAV-induced proinflammatory mediators. a The effect of $\beta$-sitosterol on ISRE luciferase reporter activity in IAV-infected cells. A549 cells were co-transfected with $0.5 \mu \mathrm{g}$ of pISRE-TA-luc reporter plasmid and $0.05 \mu \mathrm{g}$ of pRL-TK plasmid as described in the Materials and Methods. At $6 \mathrm{~h}$ posttransfection, the cells were infected with IAV and treated with $\beta$ sitosterol. After $24 \mathrm{~h}$, the cells were lysed, and luciferase activity was measured. ${ }^{\# \#} P<0.01$ versus the control group. ${ }^{*} P<0.05$, ${ }^{* *} P<0.01$ versus the IAV control group. b RIG-I knockdown by specific siRNAs in IAV-infected cells was confirmed by immunoblotting. c The effect of RIG-I knockdown by specific siRNAs on ISRE luciferase reporter activity in IAV-infected cells. ${ }^{\# \# \# ~} P<0.001$ versus the control group. ${ }^{* * *} P<0.001$ versus the IAV control group. $\mathbf{d}$ The effect of $\beta$-sitosterol on ISRE luciferase reporter activity induced by stimulation with a combination of IFN- $\beta$ and IAV. After $6 \mathrm{~h}$ of transfection, A549 cells were pretreated with IFN- $\beta$ ( $500 \mathrm{ng} / \mathrm{mL}$ ) (columns $4-7)$ for $4 \mathrm{~h}$ or infected with IAV prior to IFN $\beta$ stimulation (columns 8-11) for $4 \mathrm{~h}$. IFN- $\beta$-pretreated cells were infected with IAV in the presence or absence of $\beta$-sitosterol (150-450 $\mu \mathrm{g} / \mathrm{mL}$ ). IAV-infected cells were stimulated with IFN- $\beta(500 \mathrm{ng} / \mathrm{mL})$ in the presence or absence of $\beta$-sitosterol $(150-450 \mu \mathrm{g} / \mathrm{mL})$. The cells were harvested and subjected to a luciferase assay at $24 \mathrm{~h}$ p.i. ${ }^{\#} P<0.05$ versus the IAV control group (column 3 ). ${ }^{*} P<0.05$ versus the IFN- $\beta$-pretreated group (column 4). ${ }^{\S} P<0.05$ versus the group infected with IAV before being stimulated with IFN- $\beta(500 \mathrm{ng} / \mathrm{mL}$ ) stimulation group (column 8 ). e The effect of $\beta$-sitosterol on the IFN- $\beta$-mediated amplification of IAV-induced proinflammatory cytokines and chemokines at the mRNA levels was determined by real-time PCR. ${ }^{\# \# \#} P<0.001$ versus the IAV control group (column 2 ). ${ }^{*} P<0.05,{ }^{* *} P<0.01$, ${ }^{* * *} P<0.001$ versus IFN- $\beta$-pretreated group (column 3). ${ }^{\S} P<0.05,{ }^{\S \S} P<0.01$ versus the group infected with IAV before being stimulated with IFN- $\beta$ (500 ng/mL) (column 7). f The effect of $\beta$-sitosterol on the IFN- $\beta$-mediated amplification of IAV-induced proinflammatory cytokines and chemokines at the protein level was determined by a multiplex Luminex assay. ${ }^{\#} P<0.05$, ${ }^{\# \#} P<0.01$ versus the IAV control group (column 3 ). ${ }^{*} P<0.05,{ }^{* *} P<0.01$, ${ }^{* * *} P<0.001$ versus IFN- $\beta$-pretreated group (column 4). ${ }^{{ }} P<0.05,{ }^{\S \S} P<0.01,{ }^{\S \S \S} P<0.001$ versus the group infected with IAV before being stimulated with IFN- $\beta$ $(500 \mathrm{ng} / \mathrm{mL}$ ) (column 8). g The effect of IFN- $\beta$ neutralization on the IFN- $\beta$-mediated amplification of the IAV-induced proinflammatory response. A549 cells prestimulated with IFN- $\beta(500 \mathrm{ng} / \mathrm{mL})$ for $4 \mathrm{~h}$ were treated with an IFN- $\beta$ neutralizing antibody $(2.5 \mu \mathrm{g} / \mathrm{mL})$ prior to infection with IAV. After $24 \mathrm{~h}$, the culture supernatants were collected to measure proinflammatory mediator levels by a multiplex Luminex assay. ${ }^{* * *} P<0.001$ versus IAV control group. NS, not significant. $\mathbf{h}$ The effect of $\beta$-sitosterol on the IFN- $\beta$-mediated activation of STAT1. Lanes 1-3: A549 cells were treated with either IFN- $\beta(500 \mathrm{ng} / \mathrm{mL})$ or with IAV for $24 \mathrm{~h}$. Lanes 4-7: A549 cells were pretreated with IFN- $\beta$ ( $500 \mathrm{ng} / \mathrm{mL})$ for $4 \mathrm{~h}$ prior to IAV infection. Lanes 8-11: A549 cells were infected with IAV for $4 \mathrm{~h}$ and then stimulated with $500 \mathrm{ng} / \mathrm{mL}$ IFN- $\beta$. After the indicated treatments, the cells were incubated with or without $\beta$-sitosterol for $24 \mathrm{~h}$. The cell lysates were analyzed by immunoblotting for the expression of phospho-STAT1 and phospho-STAT2. $\mathbf{i}, \mathbf{j}$ The effect of $\beta$-sitosterol on the expression of RIG-I. A549 cells were pretreated with IFN$\beta(500 \mathrm{ng} / \mathrm{mL})$ for $4 \mathrm{~h}$ and infected with IAV in the presence or absence of $\beta$-sitosterol $(150-450 \mu \mathrm{g} / \mathrm{mL})$ (columns 3-6, lanes 4-7). Meanwhile, A549 cells were infected with IAV for $4 \mathrm{~h}$ prior to IFN- $\beta(500 \mathrm{ng} / \mathrm{mL})$ stimulation (columns 7-10, lanes $8-11)$. i The expression of RIG-I was determined by quantitative real-time PCR. ${ }^{\# \#} P<0.01$ versus the IAV control group (column 2 ). ${ }^{*} P<0.05,{ }^{* *} P<0.01,{ }^{* * *} P<0.001$ versus IFN- $\beta$ pretreated group (column 3). j The expression of RIG-I was determined by immunoblotting at $24 \mathrm{~h}$ p.i. The band intensities of RIG-I were semiquantified using imageJ (normalized to the loading control GAPDH). ${ }^{*} P<0.05$ versus IFN- $\beta$-pretreated group (column 4 ). ${ }^{\S} P<0.05$ versus the group infected with IAV before being stimulated with IFN- $\beta(500 \mathrm{ng} / \mathrm{mL})$ (column 8).

(Fig. 5b). To determine whether the inhibitory effect of $\beta$-sitosterol on RIG-I-mediated apoptosis is related to alterations in the expression of pro-apoptotic factors, we quantified TRAIL and sFas ligand levels in the supernatants of viral RNA-transfected cells. TRAIL and sFas ligand levels were significantly reduced by $\beta$ sitosterol treatment (Fig. 5c). Next, we determined the effect of $\beta$ sitosterol on the apoptosis of IAV-infected cell. $\beta$-Sitosterol treatment reduced IAV-mediated apoptosis and active caspase-3 and PARP (Fig. $5 d$, e). Last, we observed that $\beta$-sitosterol treatment blocked the increase in the release of TRAIL and sFas ligand in IAVinfected cells (Fig. 5f). Furthermore, RIG-I knockdown by specific siRNAs was demonstrated to significantly decrease IAV-mediated apoptosis and the release of TRAIL (Fig. $5 \mathrm{~g}, \mathrm{~h}$ ). However, the combination of RIG-I siRNAs and $\beta$-sitosterol did not have an additive effect on the inhibition of IAV-mediated apoptosis and TRAIL release, which indicated that $\beta$-sitosterol decreased IAVmediated apoptosis via the inhibition of RIG-I. Given that vRNA ( $5^{\prime}$ ppp-RNA) recognition is associated with the rapid induction of IFNs, we wondered whether $\beta$-sitosterol treatment affects IFN induction in the context of vRNA transfection. As shown in Fig. 5i, the upregulated expression of both type I IFN (IFN- $\beta$ ) and type III IFN (IFN- $\lambda 1$ ) in response to vRNA was reversed by $\beta$-sitosterol treatment in a dose-dependent manner.

To further explore whether the signaling cascade underlying RIG-I-mediated apoptosis and IFN induction is affected by $\beta$ sitosterol, we performed immunoblot analysis $24 \mathrm{~h}$ after the 
a
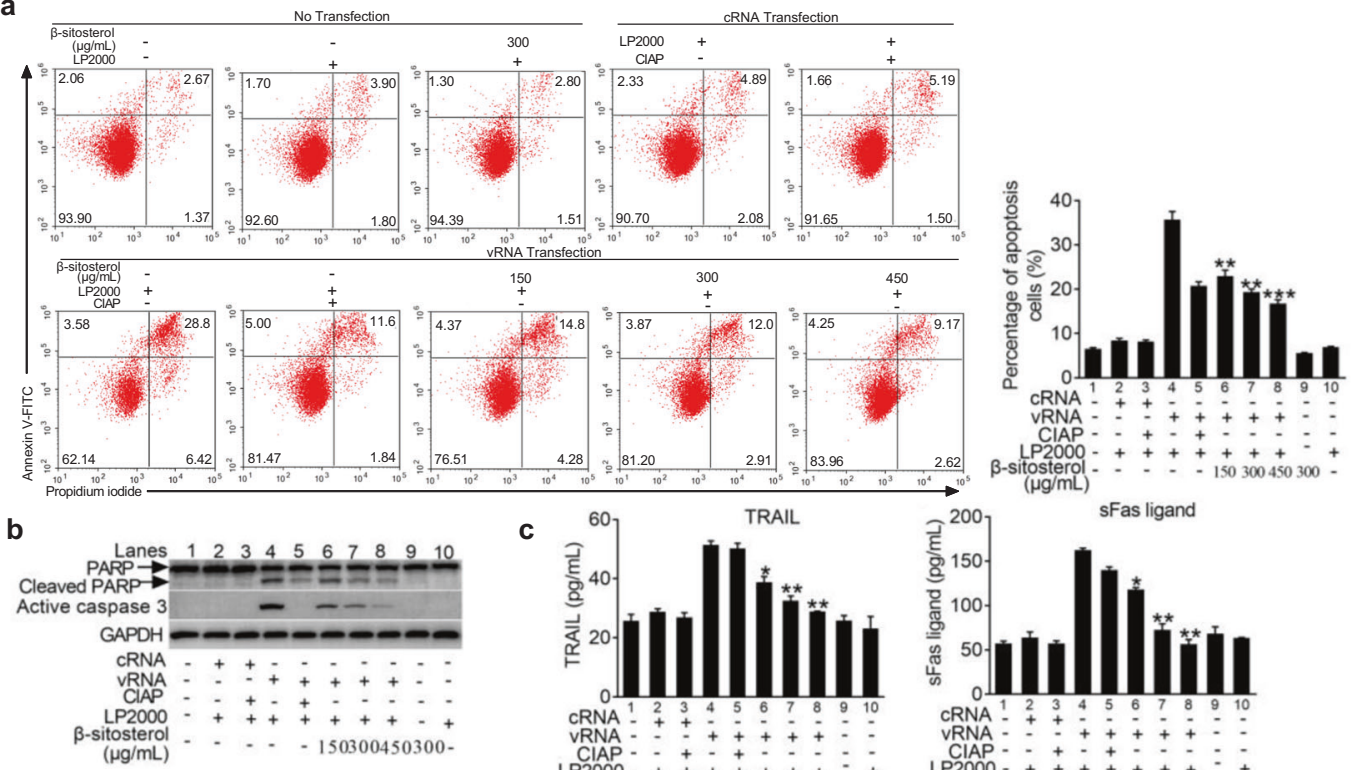

C

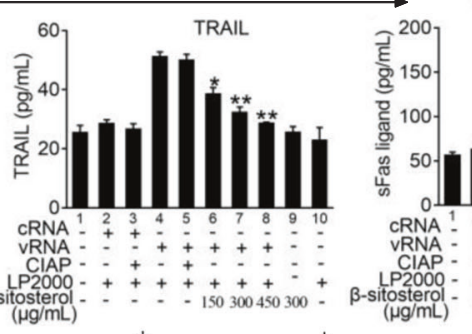

d
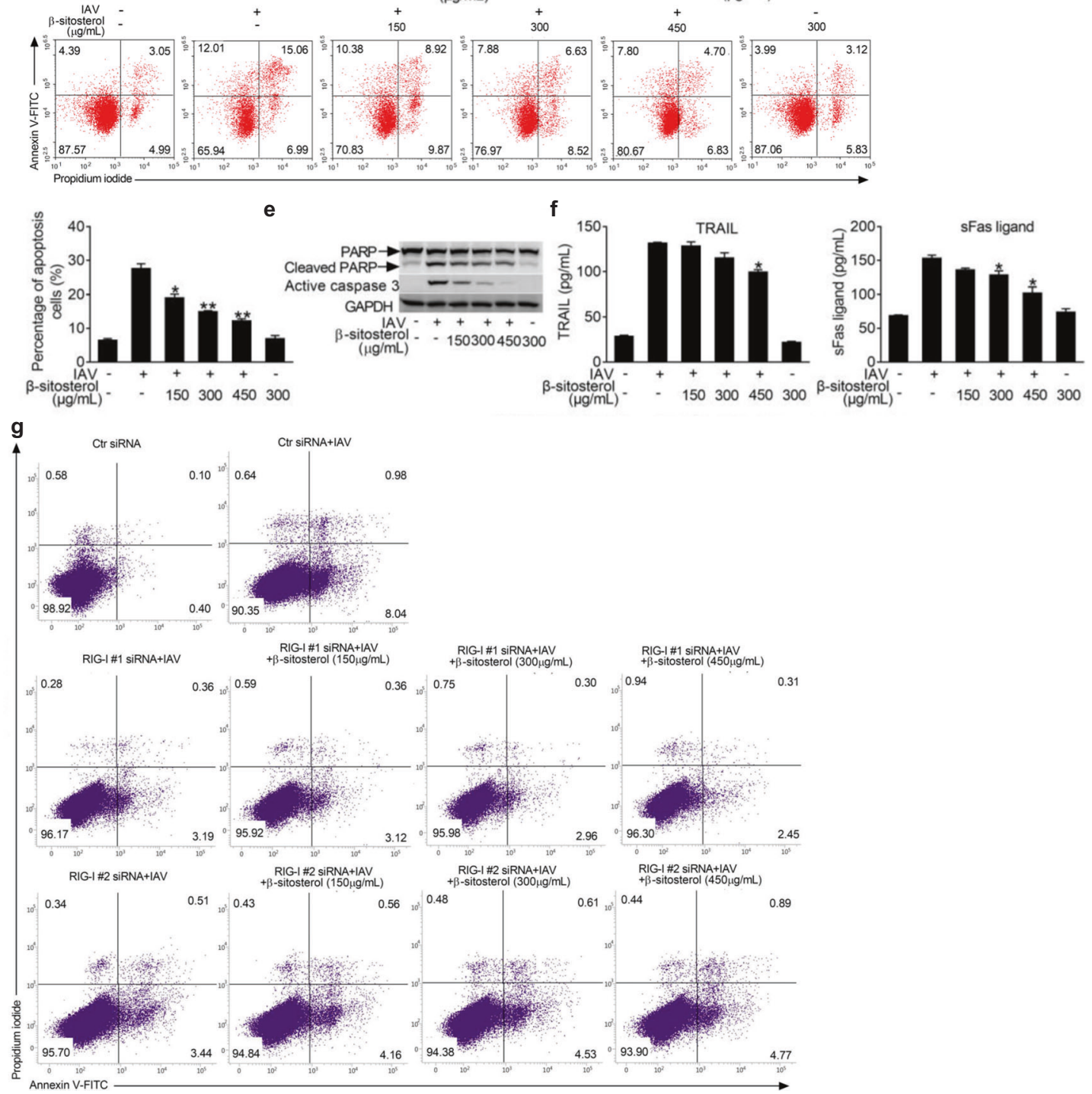

Fig. 5 (continued) 


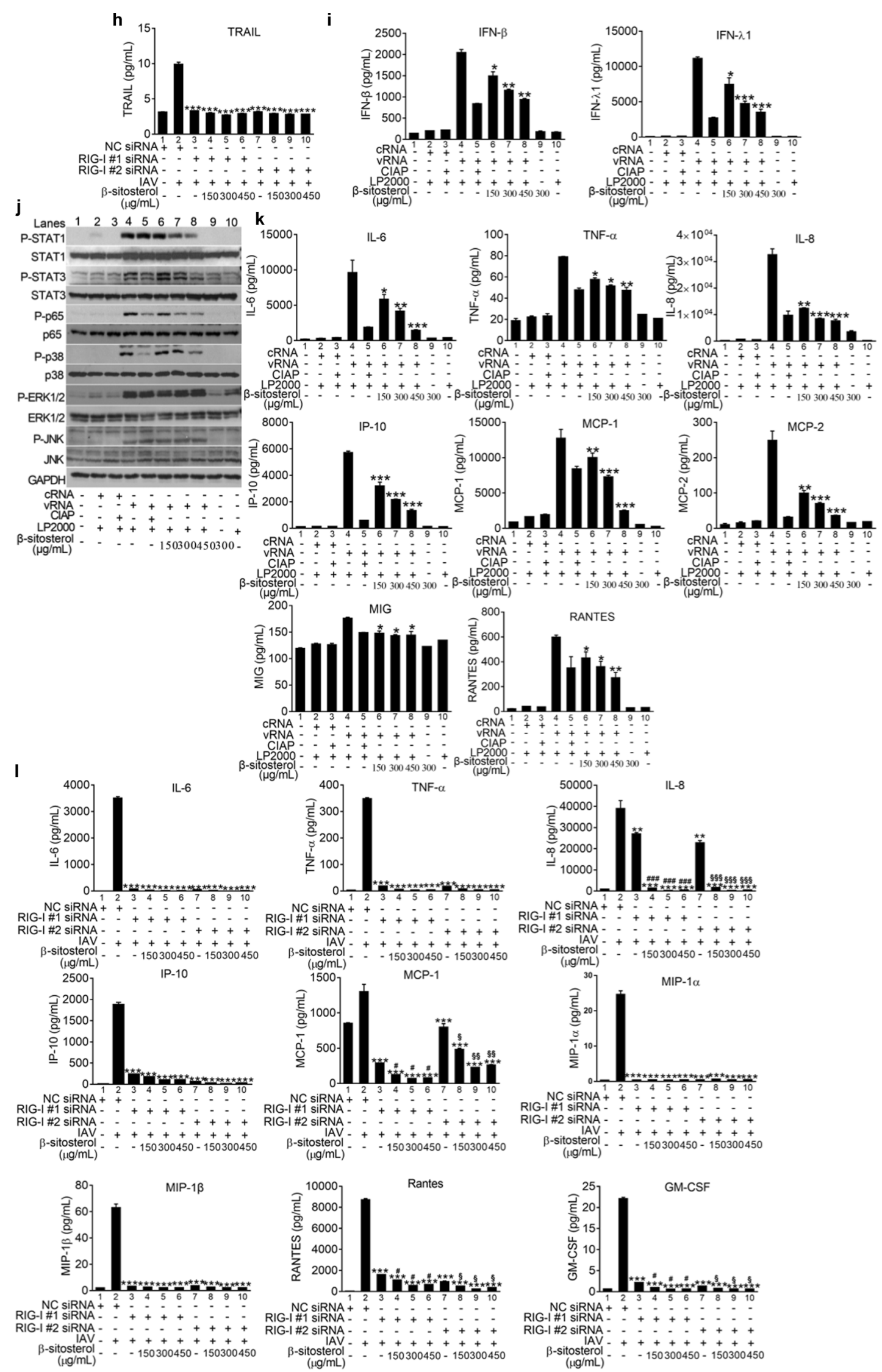

Fig. 5 (continued) 
m

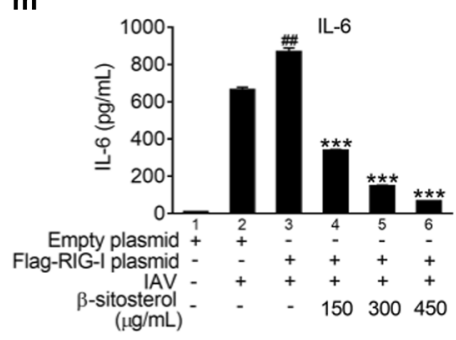

n

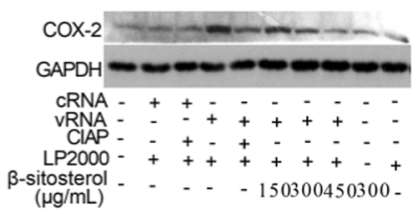

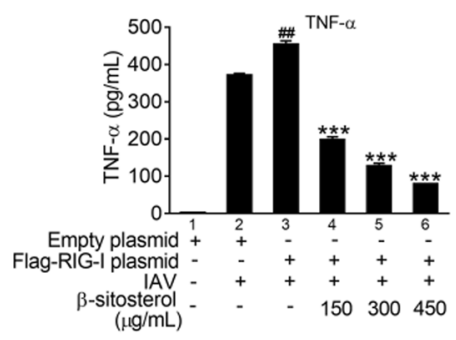

o

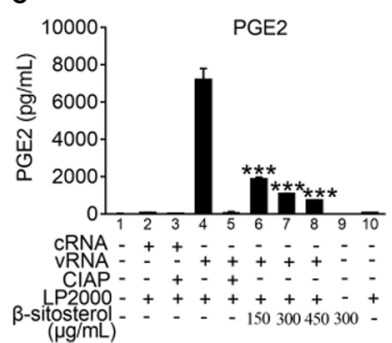

$(\mu \mathrm{g} / \mathrm{mL})$

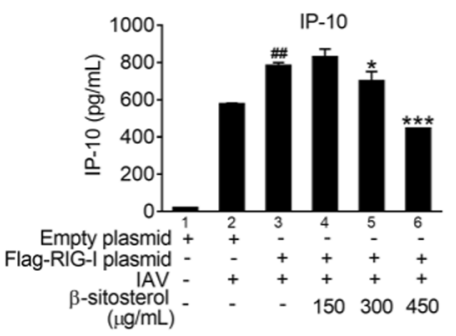

Fig. 5 Effect of $\beta$-sitosterol on RIG-I-induced apoptosis and inflammation. a Flow cytometry analysis of the effect of $\beta$-sitosterol on apoptotic A549 cells transfected with viral RNA (5'ppp-RNA) for $24 \mathrm{~h} .{ }^{* *} P<0.01, * * * P<0.001$ versus the vRNA transfection group (column 4). b Analysis of active caspase-3 and PARP cleavage in A549 cells transfected with vRNA at $24 \mathrm{~h}$. c Luminex assay for TRAIL and sFas ligand levels in the supernatants of A549 cells transfected with vRNA. ${ }^{*} P<0.05$, ${ }^{* *} P<0.01$ versus the vRNA transfection group (column 4). d Flow cytometry analysis of the effect of $\beta$-sitosterol on apoptotic A549 cells infected with IAV at $24 \mathrm{~h}$. ${ }^{*} P<0.05$, ${ }^{* *} P<0.01$ versus IAV control group. e Analysis of active caspase-3 and PARP cleavage in A549 cells infected with IAV at $24 \mathrm{~h}$. $\mathrm{f} \mathrm{Luminex}$ assay for TRAIL and sFas ligand levels in the supernatants of A549 cells infected with IAV at $24 \mathrm{~h} .{ }^{*} P<0.05$ versus the IAV control group. $\mathbf{g}$ Flow cytometry analysis of the effect of RIG-I knockdown by specific siRNAs on IAV-induced apoptosis. $\mathbf{h}$ Luminex assay for TRAIL in the supernatants of A549 cells with RIG-I knockdown. ${ }^{* * *} P<0.001$ versus IAV control group (column 2). i Luminex assay for IFN- $\beta$ and IFN- $\lambda 1$ levels in the supernatants of A549 cells transfected with vRNA at $24 \mathrm{~h} .{ }^{*} P<0.05,{ }^{* *} P<0.01,{ }^{* * *} P<0.001$ versus the vRNA-transfected group (column 4). $\mathbf{j}$ A549 cells were transfected with vRNA in the presence or absence of the indicated concentration of $\beta$-sitosterol; $24 \mathrm{~h}$ later, the cells were lysed and analyzed by immunoblotting with the indicated antibodies. GAPDH was used as a control for equal loading. $\mathbf{k}$ The effect of $\beta$-sitosterol on the protein expression of cytokines and chemokines in the supernatants of vRNA-transfected cells. ${ }^{*} P<0.05,{ }^{* *} P<0.01,{ }^{* *} P<0.001$ versus the vRNA transfection group (column 4 ). I Luminex assay for proinflammatory mediators in the supernatants of A549 cells with knockdown of RIG-I or in combination with $\beta$-sitosterol treatment. $* * * P<$ 0.001 versus the IAV control group (column 2). ${ }^{\#} P<0.05$, ${ }^{\# \# \#} P<0.001$ versus the RIG-I \#1 siRNA transfection group (column 3 ). ${ }^{\S} P<0.05,{ }^{5 \S} P<$ 0.01 , ${ }^{\S \S} P<0.001$ versus the RIG-I \#2 SiRNA transfection group (column 7 ). $\mathbf{m}$ Luminex assay for cytokines and chemokines in the culture supernatants of IAV-infected A549 cells transfected with Flag-RIG-I overexpression plasmid with or without $\beta$-sitosterol treatment. ${ }^{\# \#} P<0.01$ versus the IAV control group (column 2). ${ }^{*} P<0.05,{ }^{* * *} P<0.001$ versus the Flag-RIG-I overexpression plasmid transfection control group (column 3). $\mathbf{n}$ The effect of $\beta$-sitosterol on the expression of COX-2 in vRNA-transfected cells. The cells were transfected with vRNA in the presence or absence of the indicated concentration of $\beta$-sitosterol; $24 \mathrm{~h}$ later, the cells were lysed and analyzed by immunoblotting using a specific antibody to COX-2. o Quantification of PGE2 in the culture supernatants of vRNA-transfected cells in the presence or absence of the indicated concentrations of $\beta$-sitosterol at $24 \mathrm{~h}$. ${ }^{* *} P<0.001$ versus the vRNA-transfected group (column 4).

intracellular delivery of vRNA. vRNA transfection resulted in substantial activation of NF-KB, MAPK, and JAK/STAT signaling (Fig. 5j) (lane 4). Notably, the dephosphorylation of the 5'triphosphate of RNA led to the inactivation of p65 NF-KB and p38 MAPK but not STAT1 (lane 5). Moreover, the vRNA-triggered activation of p65 NF-KB, p38 MAPK, and STAT1 was inhibited by $\beta$ sitosterol (lanes 6-8). The stimulation of RIG-I with vRNA initiated signaling events that ultimately led to the expression of proinflammatory cytokines. We detected increased expression of proinflammatory mediators after $24 \mathrm{~h}$ of VRNA stimulation, and observed that $\beta$-sitosterol treatment blocked this effect (Fig. 5k). Meanwhile, these proinflammatory mediators induced by IAV were effectively reduced by specific RIG-I siRNAs (Fig. 5I). The levels of IL-8, MCP-1, Rantes, and GM-CSF were further reduced by the combination of RIG-I siRNAs and $\beta$-sitosterol (Fig. 5I). Furthermore, the further increased levels of IL-6, TNF- $\alpha$, and IP10 in Flag-RIG-I overexpression plasmid-transfected cells with IAV infection is dose-dependently decreased by $\beta$-sitosterol treatment (Fig. $5 \mathrm{~m}$ ).

Interestingly, the viral RNA-induced upregulation of COX-2 expression was decreased following $\beta$-sitosterol treatment (Fig. $5 \mathrm{n}$ ). To further confirm that $\beta$-sitosterol suppresses viral RNA-mediated COX-2 upregulation, we quantified the level of its downstream product PGE2 in the culture medium using ELISA. Our results showed that treatment with $\beta$-sitosterol dosedependently suppressed the viral RNA-induced production of PGE2 (Fig. 5o). Collectively, these data suggest that $\beta$-sitosterol inhibits the activation of RIG-I signaling and downstream apoptosis in response to vRNA.

$\beta$-Sitosterol ameliorates IAV-induced lung pathology in mice linked to T-cell infiltration

Considering that $\beta$-sitosterol exhibited immunomodulatory properties in vitro, we next sought to investigate whether $\beta$-sitosterol has a protective effect in a mouse model of influenza. BALB/c mice were pretreated with $\beta$-sitosterol for 2 days prior to intranasal challenge with $5 \mathrm{LD}_{50}$ of IAV. At 5 days p.i., histological analysis of lung sections showed that infection with IAV resulted in extensive inflammation characterized by massive leukocyte recruitment to the lung parenchyma (Fig. 6a, upper panel). Pre-treatment with $200 \mathrm{mg} \cdot \mathrm{kg}^{-1} \cdot \mathrm{d}^{-1} \beta$-sitosterol decreased leukocyte infiltration, and as a result, relatively few inflammatory cells were observed surrounding the bronchioles (Fig. 6a, upper panel). We next performed immunohistochemical staining for CD3 (pan T lymphocytes) and observed that the infiltration of $\mathrm{CD}^{+}{ }^{+} \mathrm{T}$ lymphocytes was more pronounced in the lungs of mice with IAV 
a

PBS

IAV

IAV+ $\beta$-sitoterol

$\mathrm{IAV}+\beta$-sitoterol

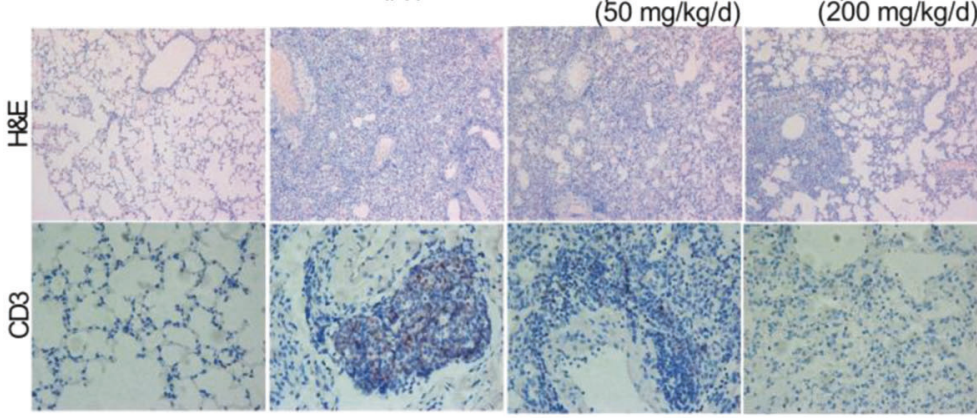

b
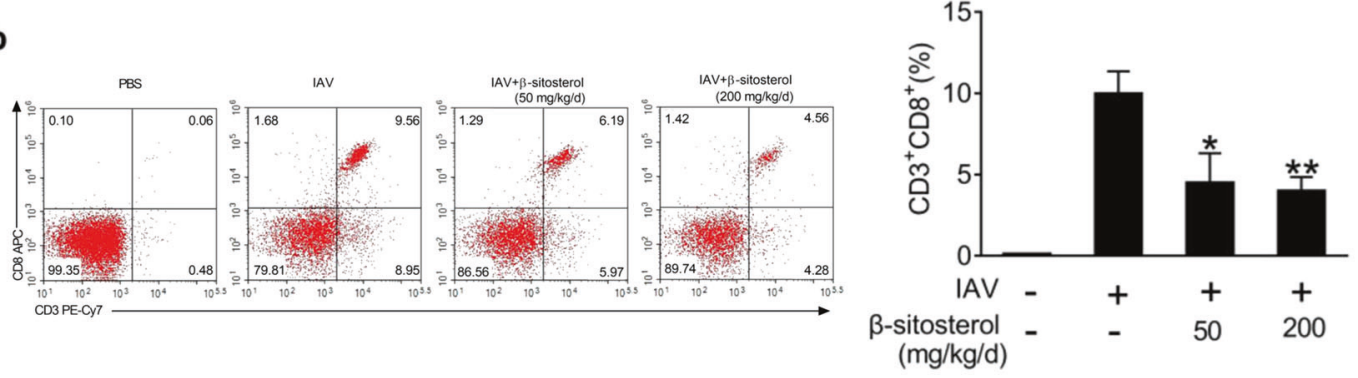

C
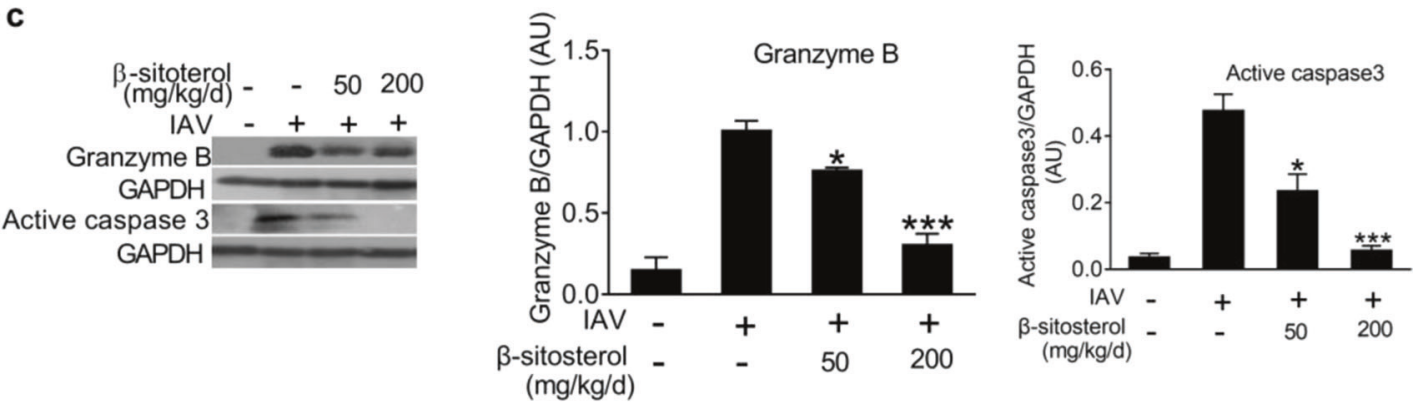

d

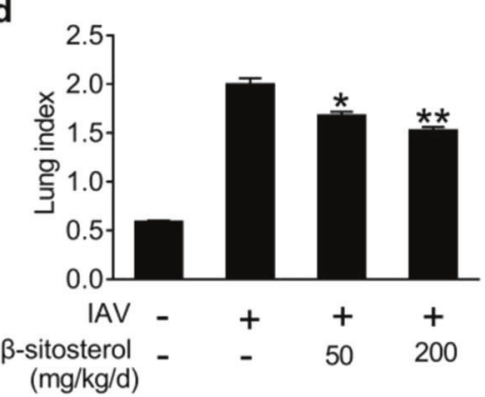

e

f
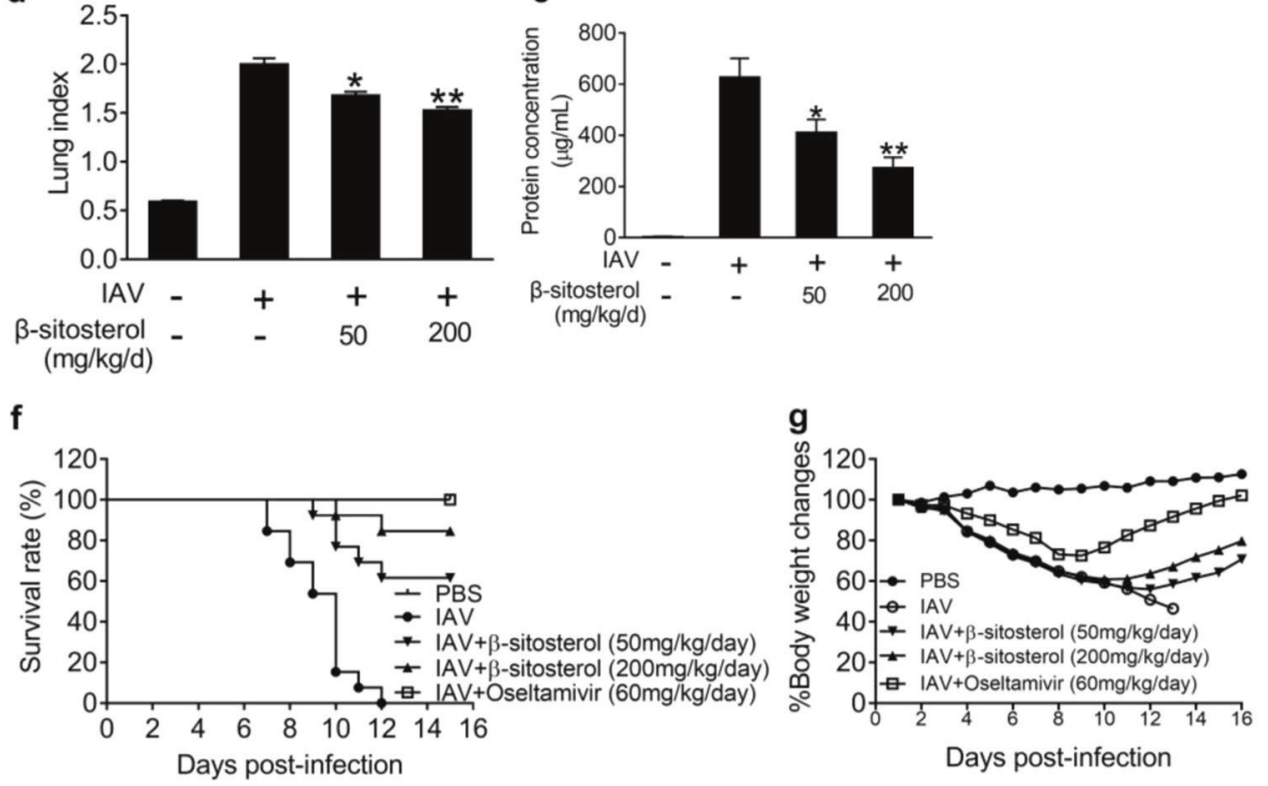

infection alone compared with those that received $\beta$-sitosterol treatment (Fig. 6a, lower panel). Consistent with the immunohistochemical results, a significantly greater percentage of $\mathrm{CD}^{+} \mathrm{CD}^{+}$cytotoxic T lymphocytes (CTLs) was detected in BALF from IAV-infected mice compared with BALF from mice treated with $\beta$-sitosterol (Fig. 6b). Moreover, the quantification of granzyme $B$, a pro-apoptotic enzyme secreted by $C T L$, in lung homogenates revealed a significant increase in its expression in IAV-infected mice that was significantly reduced by $\beta$-sitosterol administration (Fig. $6 \mathrm{c}$ ). Similar results were obtained for the levels 
Fig. 6 B-Sitosterol prevents IAV-induced lung pathology in mice. Two days prior to infection with 5 LD 50 of A/FM1/H1N1 virus, PBS or $\beta$-sitosterol $\left(50 \mathrm{mg} \cdot \mathrm{kg}^{-1} \cdot \mathrm{d}^{-1}\right.$ or $\left.200 \mathrm{mg} \cdot \mathrm{kg}^{-1} \cdot \mathrm{d}^{-1}\right)$ was intragastrically administered to mice for 7 consecutive days. a On day 5 p.i., the lungs were harvested and subsequently subjected to histological analysis by H\&E staining (original magnification, $\times 100)$ or CD3 antigen (T-cell marker) staining (original magnification, $\times 200$ ). b Representative flow cytometry quantification of $\mathrm{CD} 3^{+} \mathrm{CD} 8^{+} \mathrm{T}$ cells in BALF on day 4 p.i. The histograms represent the percentage of $\mathrm{CD}^{+} \mathrm{CD}^{+} \mathrm{T}$ cells in BALF (right panel). The data are representative of three independent experiments using 5-7 mice per group. ${ }^{*} P<0.05,{ }^{*} P<0.01$ versus the IAV-infected group. c On day 5 p.i., the lungs were removed and homogenized. Lung homogenates were subjected to immunoblot analysis of granzyme $B$ and active caspase-3. The ratios of the relative band intensities of granzyme $B$ and active caspase- 3 normalized to GAPDH are shown $\left(n=3-5\right.$ mice per group) (right panel). ${ }^{*} P<0.05, * * * P<0.001$ versus the IAV-infected mice group. d The lung index (lung/body weight ratios) of mice treated with PBS $(n=6)$ or $\beta$-sitosterol $(n=6)$ on day 5 p.i. ${ }^{*} P<0.05,{ }^{* *} P<0.01$ versus the IAV-infected group. e On day 7 p.i., the total protein concentrations in BALF was measured by BCA assay ( $n=3-11$ mice per group). ${ }^{*} P<0.05,{ }^{*} P<0.01$ versus the IAV-infected group. $\mathbf{f}, \mathbf{g}$ Survival rate (f) and weight curves (g) of IAV-infected mice treated with or without $\beta$-sitosterol ( $n=13$ mice per group).

of active caspase-3 measured by immunoblotting (Fig. 6c). Although influenza antigen-specific $\mathrm{CD}^{+} \mathrm{T}$ cells are recruited to the sites of infection and contribute to viral clearance, immunemediated lung injury can be elicited by aberrant T-cell responses. Lung index and total protein levels in BALF can be used as an assessment of lung damage. Our results showed that compared with IAV infection alone, $\beta$-sitosterol treatment produced a significantly lower lung index and protein levels in BALF (Fig. $6 \mathrm{~d}$, e), suggesting that $\beta$-sitosterol treatment alleviated lung injury likely through the suppression of $\mathrm{CD}^{+} \mathrm{T}$-cell recruitment. Last, IAV infection resulted in $100 \%(13 / 13)$ mortality by 12 days p.i. and rapid and continuous weight loss (Fig. 6f, g). Remarkably, the survival rate of mice that were treated with 50 and $200 \mathrm{mg} / \mathrm{kg} \beta$ sitosterol was significantly increased to $61.5 \%(8 / 13)$ and $84.6 \%$ $(11 / 13)$, respectively. Furthermore, $\beta$-sitosterol-treated mice exhibited less initial weight loss after viral challenge and a gradual recovery of body weight (Fig. $6 \mathrm{~g}$ ). Together, these data reveal that $\beta$-sitosterol attenuates IAV-induced lung injury and reduces mortality.

$\beta$-Sitosterol protects against IAV by abrogating the IAV-mediated activation of multiple signaling cascades

To investigate the mechanisms underlying the protective effect of $\beta$-sitosterol against IAV in vivo, we focused on inflammationassociated signal transduction in the lung. The phosphorylation levels of STAT1, STAT3, P38, and ERK1/2 in lung homogenates were significantly increased in mice challenged with IAV relative to uninfected mice (Figs. 7a), whereas the phosphorylation levels of these molecules were decreased in mice treated with $\beta$-sitosterol. To address whether $\beta$-sitosterol inhibits the signaling events mediating the IAV-induced expression of proinflammatory cytokines, we quantified cytokine and chemokine levels using luminex. The expression of cytokines and chemokines in BALF (IL-6, TNF-a, Rantes, KC, MCP-1 and MIP-1a) and lung homogenates (IL-6, TNF-a, IP-10, and Rantes) was reduced in mice treated with $\beta$-sitosterol (Fig. 7b, c). The IAV-induced elevation of serum cytokines including IFN- $\gamma$, IP-10, and Rantes, was blocked in $\beta$-sitosterol-treated mice (Fig. 7d). Given that $\beta$-sitosterol inhibited IAV-mediated STAT1/3 activation in vivo and decreased the expression of RIG-I and IFN in vitro (Fig. $3 \mathrm{~b}, \mathrm{f}$ ), it was necessary to examine the impact of $\beta$-sitosterol treatment on the expression of RIG-I and IFNs in vivo. As expected, IAV-induced expression of RIG-I in lung homogenates was decreased by $\beta$-sitosterol treatment (Fig. 7e). Similarly, the expression of IFNs in BALF (IFN- $\alpha$, IFN- $\beta$, and IFN- $\gamma$ ) (Fig. 7f) and lung homogenates (IFN- $\beta$ ) (Fig. 7g) was also decreased. Collectively, these data provide evidence regarding the mechanism by which $\beta$-sitosterol modulates dysregulated signaling cascades and proinflammatory responses linked to severe influenza.

\section{DISCUSSION}

Patients with influenza are frequently afflicted with severe pneumonia characterized by excessive infiltration of leukocytes and proinflammatory cytokine production [58-60], leading to a high risk of death. Recent studies have revealed that IAV-mediated IFNs play a disease-promoting role in the pathogenesis of influenza [31]. Chinese herbal medicines, including $L$. japonica [35], C. morifolium [36], T. mongolicum [37], F. suspense [38], and $I$. indigotica [39], have a long history of being used for the treatment of the common cold and for heat-clearing. In the current study, we demonstrated that $\beta$-sitosterol derived from these herbal medicines has the ability to block IAV-mediated IFN and proinflammatory mediator production through the inhibition of RIG-I signaling. Furthermore, our data showed that $\beta$-sitosterol attenuates the amplification of the IAV-mediated proinflammatory response in IFN-sensitized cells by disrupting RIG-I-mediated STAT1 activation. Furthermore, we showed that $\beta$-sitosterol abrogates the recruitment of cytotoxic T lymphocytes (CTLs) in the lung, thereby significantly improving lung injury and survival in mice challenged with IAV (Fig. 8).

RIG-I detects viral RNA (5'ppp-RNA) in the cytoplasm, which is then ubiquitinated by TRIM25 (tripartite motif-containing protein 25) and subsequently interacts with IPS-1 (IFN- $\beta$ promotor stimulator 1) to initiate the activation of NF-KB, p38, and IRF3/7 $[61,62]$. We asked whether RIG-I signaling is affected by $\beta$ sitosterol during IAV infection or in cells transfected with viral RNA. We found that RIG-I expression was increased following IAV infection or prestimulation with IFN- $\beta$ prior to IAV infection, and that this increase in expression was significantly reduced in the presence of $\beta$-sitosterol. Furthermore, the activation of NF-KB and p38 in both IAV-infected and viral RNA-transfected cells was inhibited by $\beta$-sitosterol treatment. These results suggest that $\beta$ sitosterol treatment antagonizes the RIG-I signaling cascades.

The activation of RIG-I and its downstream targets NF-KB and p38 contributes to the induction of proinflammatory cytokines in response to influenza virus infection [63]. In previous studies, the upregulation of RIG-I during fatal H5N1 infection was shown to cause an amplification of inflammatory responses [18]. The hyperinduction of proinflammatory cytokines via RIG-I, NF-KB, and p38 signaling has been suggested to contribute to severity of symptoms in patients with $\mathrm{H} 5 \mathrm{~N} 1$ infection $[64,65]$. We measured NF-KB activation using an NF-KB luciferase reporter system and found that $\beta$-sitosterol treatment downregulated the transcriptional activation of NF-KB following the administration of TNF- $\alpha$ and IAV infection. Consistent with these findings, the inhibitory effects of $\beta$-sitosterol on RIG-I signaling led to reduced production of cytokines, such as IL- 6 and TNF- $\alpha$, and chemokines such as IL-8 and IP-10 in IAV-infected and viral RNA-transfected cells. RIG-I or NF-KB and p38 activation in response to viral or bacterial infection, respectively, has been reported to induce COX-2 expression [46, 66]. Furthermore, it has been shown that decreased expression of COX-2 and its derivative PGE2 has beneficial effects during influenza virus infection that lead to reduced hypothermia and enhanced type I IFN antiviral immunity [51]. We observed that IAV infection and viral RNA stimulation were associated with increased expression of COX-2 and PGE2 and that $\beta$-sitosterol treatment reversed the increase in a dosedependent manner. 
a
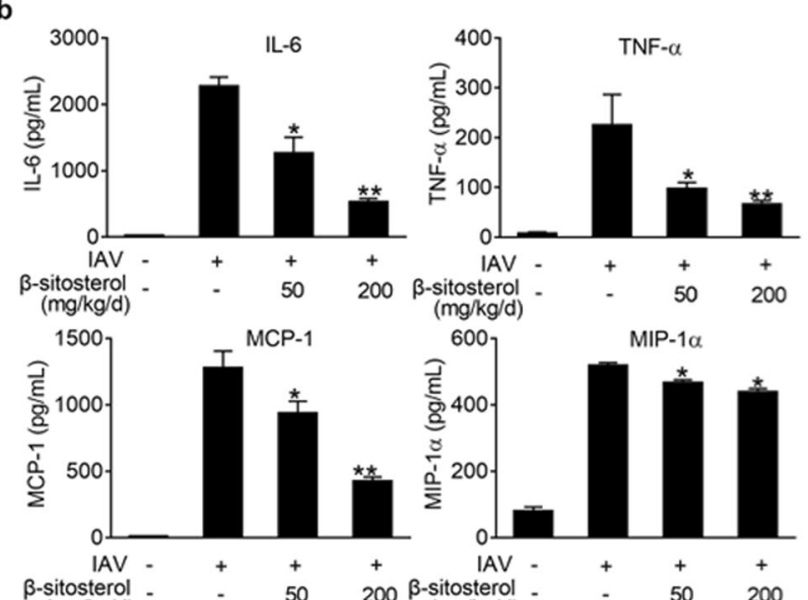

$\beta$-sitosterol . $(\mathrm{mg} / \mathrm{kg} / \mathrm{d})$

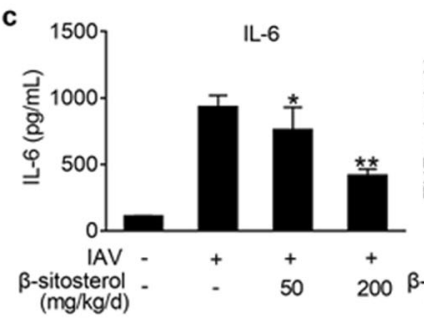

$(\mathrm{mg} / \mathrm{kg} / \mathrm{d})$
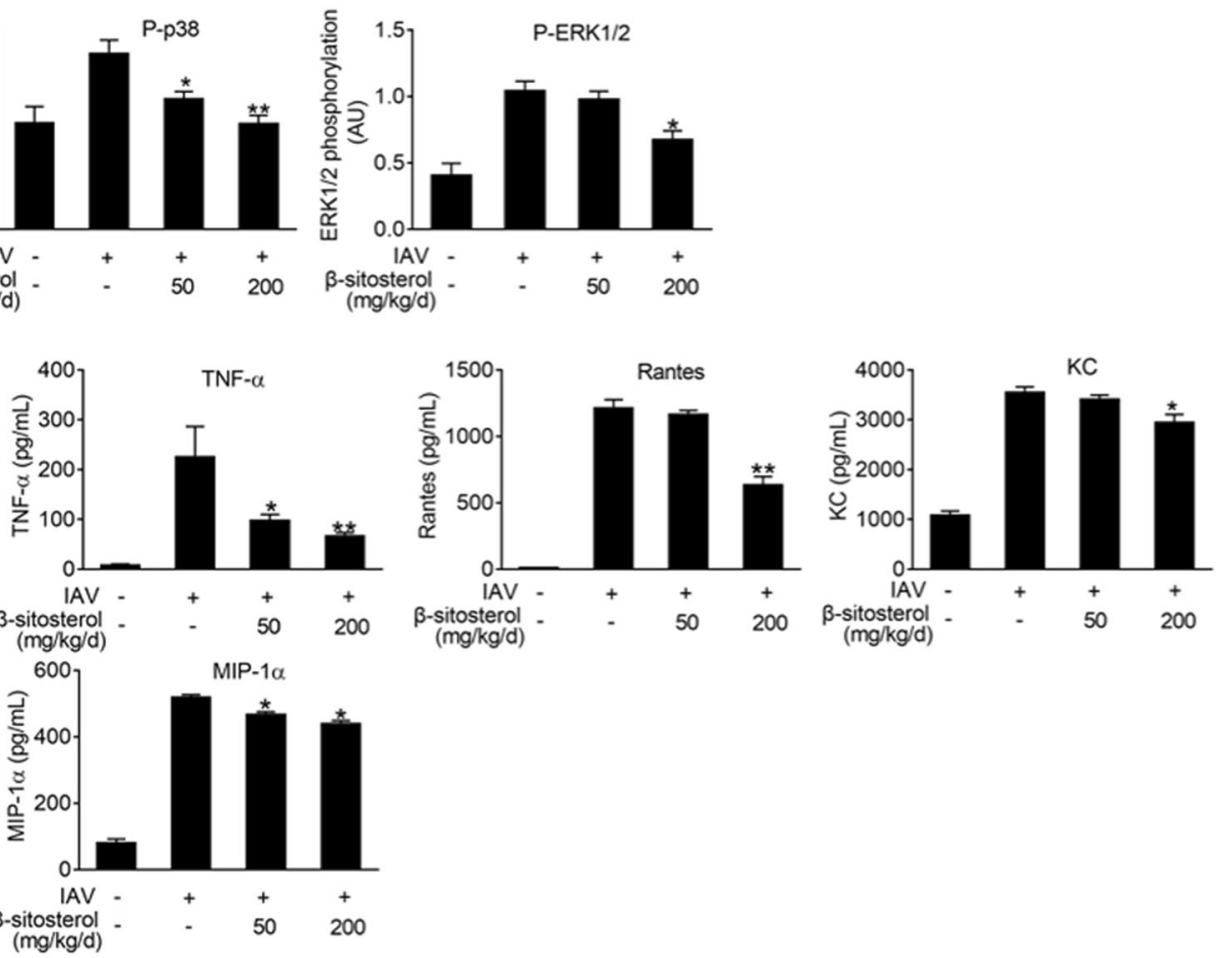

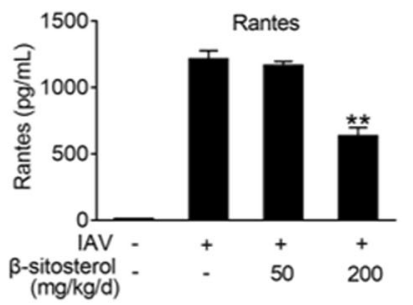

$(\mathrm{mg} / \mathrm{kg} / \mathrm{d})$

P-STAT3

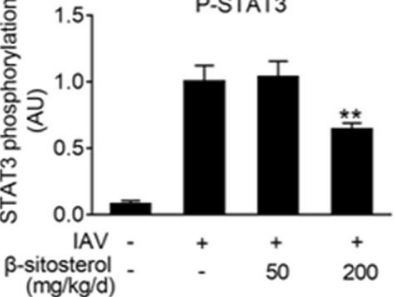

$(\mathrm{mg} / \mathrm{kg} / \mathrm{d})$
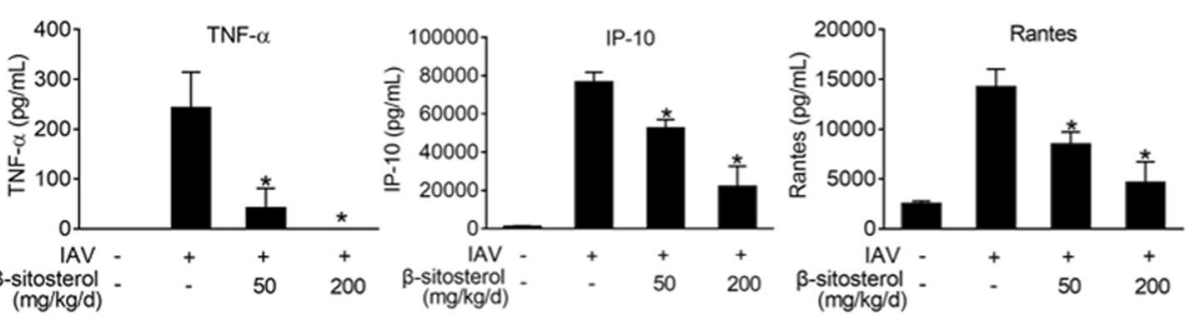

d

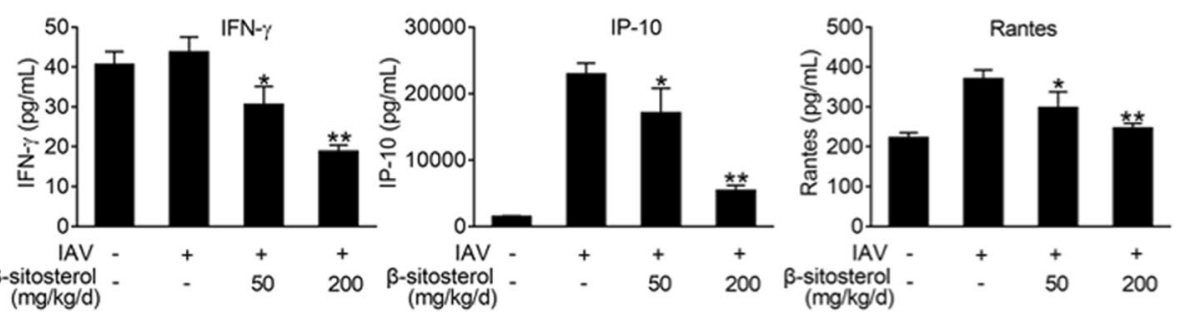

e
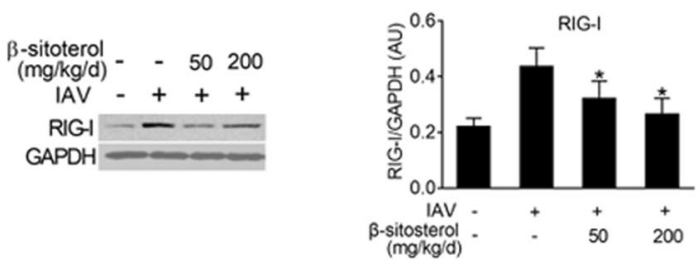

Fig. 7 (continued) 
f
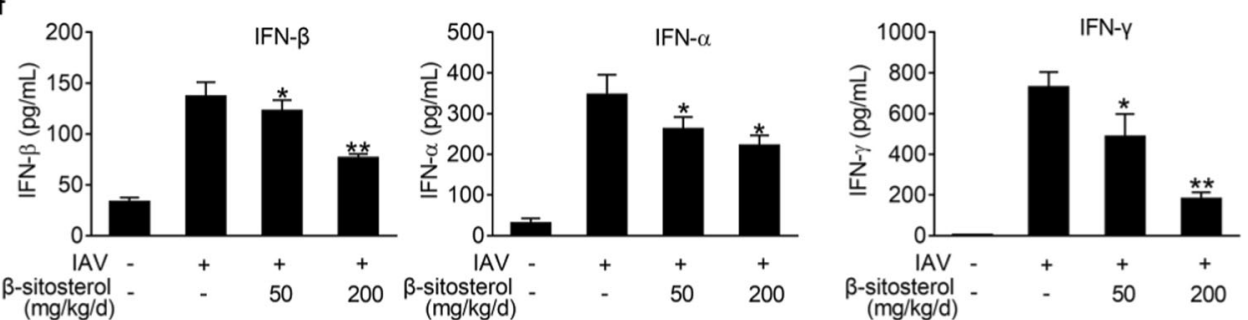

g

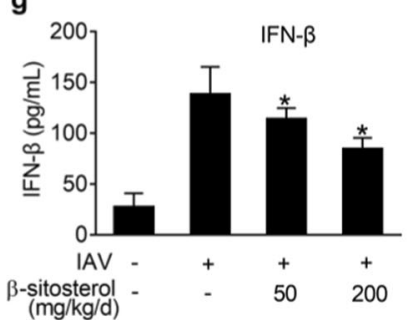

Fig. $7 \quad \beta$-Sitosterol effectively abrogates IAV-triggered signaling in vivo. a Mice were infected with 5 LD 50 of $A / F M 1 / H 1 N 1$ virus and treated with PBS or $\beta$-sitosterol (intragastrically administered for 7 consecutive days beginning 2 days prior to viral infection). The lungs were harvested and homogenized on day 5 p.i. and the processed for immunoblotting with the indicated antibodies. The relative band intensities of the indicated proteins were normalized to that of GAPDH ( $n=3-5$ mice per group) (right panel). ${ }^{*} P<0.05,{ }^{* *} P<0.01$ versus the IAV-infected group. b-d Detection of cytokine and chemokine production in BALF (b), lung homogenates (c), and serum (d) by Luminex analysis. ${ }^{*} P<0.05$, ${ }^{* *} P<0.01$ versus IAV-infected group. e On day 5 p.i., lung homogenates were subjected to immunoblot analysis of RIG-I. The RIG-I band intensity normalized to that of GAPDH is shown ( $n=4-6$ mice per group) (right panel). ${ }^{*} P<0.05$ versus IAV-infected group. $\mathbf{f}$, $\mathbf{g}$ Detection of IFNs (IFN- $\alpha$, IFN- $\beta$, and IFN- $\gamma$ ) production in BALF (f) and lung homogenates (g) by Luminex analysis. ${ }^{*} P<0.05$, ${ }^{* *} P<0.01$ versus the IAVinfected group.

NF-KB, ATF2 (a downstream target of p38), and IRF3 form a transcriptional complex that drives the expression of the antiviral factor IFN- $\beta$ [10]. In addition, the viral-induced expression of type III IFN requires the involvement of RIG-I, IPS-1, TBK1, and p38 signaling [67-69], suggesting that the expression of type I and III IFNs is promoted via a common mechanism. Interestingly, some studies have indicated that NF-KB is crucial for IFN- $\beta$ production when IRF3 activation is weak but not when IRF3 activation is strong [70]. Although we did not detect significant activation of IRF3 at $24 \mathrm{~h}$, we were able to detect an inhibitory effect of $\beta$-sitosterol on the expression of IFNs, including IFN- $\beta$ and IFN- $\lambda 1$, in cells infected with IAV or in those subjected to viral RNA transfection. These findings may be attributable to the inactivation of RIG-I, NF-KB, and p38 signaling. A clear link between RIG-I expression and STAT1 activation has been established by previous studies. Experiments involving RIG-I overexpression or knockdown have suggested that RIG-I is essential for STAT1 activation in leukemia cell lines [54, 71]. In accordance with these findings, our results show that the augmentation of STAT1 activation by RIG-I overexpression was suppressed by $\beta$-sitosterol or the inhibition of IAV-mediated ISRE transcriptional activity by specific RIG-I siRNAs. In addition, we observed that the activation of JAKs was not affected by $\beta$-sitosterol. Therefore, the inhibition of STAT1 phosphorylation in response to IFN- $\beta$ treatment for $15 \mathrm{~min}$ or $24 \mathrm{~h}$ can be attributed to the downregulation of RIG-I by $\beta$ sitosterol. Moreover, the activation of RIG-I, but not of MDA-5, has been shown to involve double-stranded RNA (dsRNA)-induced STAT1 phosphorylation [72]. Our data showed that $\beta$-sitosterol treatment abrogated STAT1 phosphorylation in cells stimulated with vRNA (5'ppp-RNA), which binds to and activates RIG-I. However, the dephosphorylation of viral RNA with CIAP did not reduce STAT1 phosphorylation. A possible explanation for these findings is that the dsRNA that is generated following viral RNA dephosphorylation is also a ligand for RIG-I and induces STAT1 phosphorylation in an IFN-dependent or IFN-independent manner, as described previously [72].
The important role of IFNs in the defense against viral infection is widely recognized $[73,74]$. However, IFN receptor deficiency does not lead to a detrimental outcome, which is perhaps due to decreased IFN-induced immune injury [31, 33, 34]. Recent studies have clearly revealed the pathogenic potential of IFN- $\beta$ - and IFN$\lambda 1$-mediated immunopathology in viral infectious diseases and autoimmune diseases [31, 33, 34, 75]. Here, we have proposed a model in which IFNs (including type I and III IFN) secreted from IAV-infected cells bind to their receptors and sensitize uninfected neighboring cells, leading to the amplification of proinflammatory responses driven by ISGF3 following infection by progeny viruses. $\beta$-Sitosterol treatment blocked the amplification of this proinflammatory response and the concomitant expression of proinflammatory cytokines through the inhibition of ISGF3 complexes. The inhibitory effect on ISGF3 complexes was due to the failure of downregulated RIG-I to exert a converse effect on STAT1 activation in $\beta$-sitosterol-treated cells (Fig. 8). The activation of RIG-I-mediated apoptosis via type I IFN-dependent and type I IFNindependent mechanisms has been considered a promising strategy for cancer therapeutics [57, 76]. The IFN-induced activation of ISGF3 leads to TRAIL expression, resulting in substantial alveolar epithelial cell (AEC) apoptosis and lung injury $[32,77]$. AEC apoptosis has been found to play a critical role in the pathogenesis of $\mathrm{H} 5 \mathrm{~N} 1$ and pandemic $\mathrm{H} 1 \mathrm{~N} 1$ in patients with ARDS $[59,78]$. Our data suggest that $\beta$-sitosterol prevents IAV-induced apoptosis associated with decreased IFN-driven expression of TRAIL.

The loss of RIG-I signaling has been correlated with a reduction in antigen presentation in bone marrow derived dendritic cells (BMDCs), and in the antiviral function of $\mathrm{CD}^{+}$cytotoxic $\mathrm{T}$ cells [79]. Thus, it is clear that the RIG-I pathway is important for mediating the production of IFNs during antiviral responses. In contrast, the RIG-I-mediated expression of inflammatory mediators has been shown to induce the recruitment of monocyte-derived DCs (moDCs) to support viral replication [80]. Antiviral effector $\mathrm{CD}^{+} \mathrm{T}$ cells and NK cells eliminate invading pathogens through 


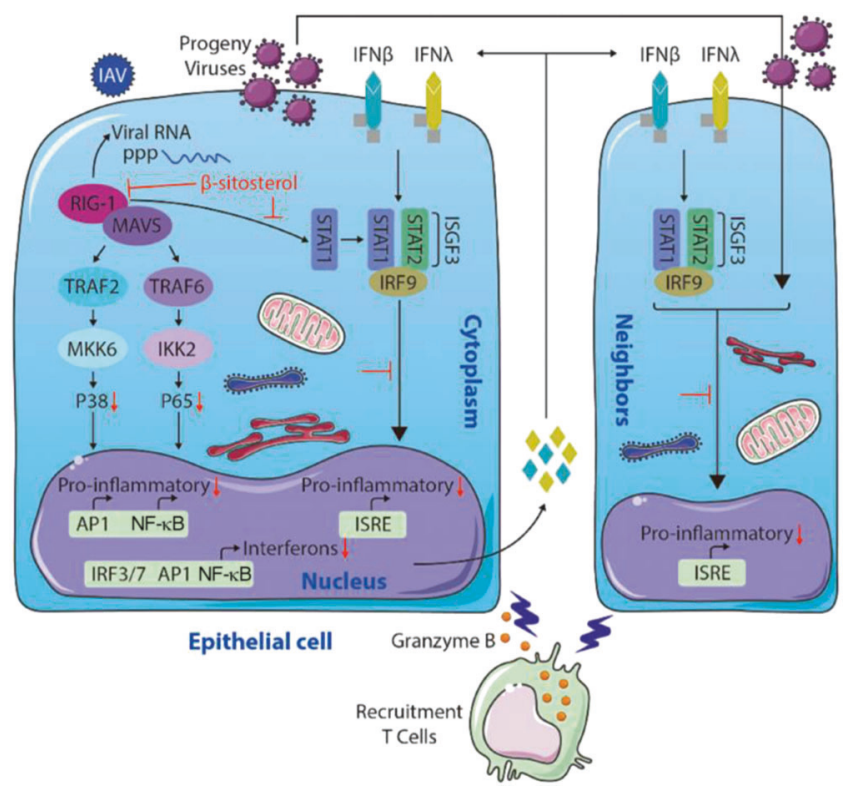

Fig. 8 Schematic diagram showing the mechanism by which $\beta$ sitosterol attenuates IAV-induced proinflammatory responses and injury. Invading viruses are sensed by RIG-I, leading to the activation and that of RIG-I, NF-KB, and p38, which initiates the expression of proinflammatory mediators and IFNs. Secreted IFNs, including type I and III IFNs, bind to their receptors via an autocrine or paracrine mechanism and then exert their antiviral effects. Subsequently, previously uninfected IFN-sensitized neighboring cells become infected by progeny viruses, which triggers the amplification of the inflammatory response. The inhibition of RIG-I signaling by $\beta$ sitosterol attenuates RIG-I-linked proinflammatory IFN production, which results in a reduction in STAT1 activation and thus a decrease in the amplification of proinflammatory responses driven by ISG complexes in IFN-sensitized cells. Furthermore, the inhibition of RIGI signaling by $\beta$-sitosterol also suppresses the recruitment of $\mathrm{CD}^{+}$ $\mathrm{T}$ cells and granzyme B release in vivo, thereby blocking lung immune injury during influenza virus infection.

several mechanisms, including the expression of pro-apoptotic proteins such as TRAIL and Fas and the secretion of granzyme B (Grb) and perforin. Through these mechanisms, the apoptotic caspase cascade is activated in virus-infected cells [81-83]. Studies have reported that IFN- $\gamma$ plays an important role in modulating $\mathrm{CD}^{+}{ }^{+}$T-cell recruitment and that the production of granzyme $\mathrm{B}$ during the recruitment of $C D 8^{+} T$ cells is dependent on the IFN- $\beta$ induced activation of STAT1 [81, 84, 85]. Accordingly, our data show that $\beta$-sitosterol administration decreases the levels of IFN- $\gamma$ and IFN- $\beta$ and concomitantly induces a low level of $\mathrm{CD} 8^{+}$T-cell recruitment and granzyme $B$ secretion in the lungs. Cytotoxic $\mathrm{CD}^{+} \mathrm{T}$ lymphocytes (CTLs) seem to be essential for viral clearance. However, severe pneumonia in patients with pandemic influenza $A(\mathrm{H} 1 \mathrm{~N} 1)$ virus infection is apparently related to high levels of $\mathrm{CD}^{+} \mathrm{T}$ cells [86]. Interestingly, one study showed that HA-transgenic mice develop lethal lung injury following treatment with influenza HA-specific $\mathrm{CD}^{+}$cytotoxic T cells [87]. Deficiency of A20 (TNF alpha-induced protein 3, TNFAIP3), which is a negative feedback ubiquitin-editing protein that inhibits NF-KB signaling, protects mice against viral challenge by reducing the population of $\mathrm{Grb}^{+} \mathrm{CD}^{+} \mathrm{T}$ cells [88]. Consistent with these studies, our data showed that IAV-induced acute lung injury and mortality are attenuated in mice treated with $\beta$-sitosterol and that this attenuation is associated with decreased $\mathrm{CD}^{+}$T-cell recruitment and granzyme $B$ secretion in the lung. Furthermore, we observed the inhibition of STAT1/3 and p38 phosphorylation by $\beta$-sitosterol in mouse lung tissue and made a similar observation in IAVinfected A549 cells. The expression of cytokines driven by STAT1/3 and p38, which exacerbate IAV-induced immunopathology, in BALF and lung tissue was decreased following $\beta$-sitosterol administration in BALF and lung tissue. In contrast to our in vitro results, the phosphorylation of ERK $1 / 2$ was attenuated in the lung tissues of $\beta$-sitosterol-treated mice. The inhibition of ERK $1 / 2$ signaling is involved in the retention of viral RNP in the nucleus, but its activation also correlates with cytokine expression [89]. It is likely that the decrease in phosphorylated ERK $1 / 2$ expression in vivo was a result of the immunoregulatory effects of $\beta$-sitosterol.

\section{ACKNOWLEDGEMENTS}

This study was funded by the National Natural Science Foundation of China (grant no. 81873065), the Secondary Development Projects of Guangdong Famous and Excellent Traditional Chinese Patent Medicines (grant no. 20174005), the Natural Science Foundation of Guangdong Province (grant no. 2018A030310172), and the China Postdoctoral Science Foundation (grant nos. $2017 \mathrm{M622652}$ and 2019M652987).

\section{AUTHOR CONTRIBUTIONS}

ZFY and NSZ conceived the study; BXZ, ZFY, and NSZ designed the study; BXZ and $X L L$ conducted the in vitro experiments; $J L$ and XPP isolated and analyzed the compound $\beta$-sitosterol; BXZ, XLL, HMJ, YBH, and PFX performed animal experiments; and $B X Z$ and $J L$ wrote the paper.

\section{ADDITIONAL INFORMATION}

The online version of this article (https://doi.org/10.1038/s41401-020-0403-9) contains supplementary material, which is available to authorized users.

Competing interests: The authors declare no competing interests.

\section{REFERENCES}

1. Hai R, Schmolke M, Leyva-Grado VH, Thangavel RR, Margine I, Jaffe EL, et al. Influenza $A(H 7 N 9)$ virus gains neuraminidase inhibitor resistance without loss of in vivo virulence or transmissibility. Nat Commun. 2013;4:2854.

2. Huang $X$, Zheng M, Wang P, Mok BW, Liu S, Lau SY, et al. An NS-segment exonic splicing enhancer regulates influenza $A$ virus replication in mammalian cells. Nat Commun. 2017;8:14751.

3. Hagau N, Slavcovici A, Gonganau DN, Oltean S, Dirzu DS, Brezoszki ES, et al. Clinical aspects and cytokine response in severe H1N1 influenza A virus infection. Crit Care. 2010;14:R203.

4. Bian JR, Nie W, Zang YS, Fang Z, Xiu QY, Xu XX. Clinical aspects and cytokine response in adults with seasonal influenza infection. Int J Clin Exp Med. 2014;7:5593-602.

5. de Jong MD, Simmons CP, Thanh TT, Hien VM, Smith GJ, Chau TN, et al. Fatal outcome of human influenza $A(\mathrm{H} 5 \mathrm{~N} 1)$ is associated with high viral load and hypercytokinemia. Nat Med. 2006;12:1203-7.

6. Chi Y, Zhu Y, Wen T, Cui L, Ge Y, Jiao Y, et al. Cytokine and chemokine levels in patients infected with the novel avian influenza A (H7N9) virus in China. J Infect Dis. 2013;208:1962-7.

7. Mogensen TH. Pathogen recognition and inflammatory signaling in innate immune defenses. Clin Microbiol Rev. 2009;22:240-73.

8. Kawaguchi A, Nagata K. De novo replication of the influenza virus RNA genome is regulated by DNA replicative helicase, MCM. EMBO J. 2007;26:4566-75.

9. Wilkins C, Gale M Jr. Recognition of viruses by cytoplasmic sensors. Curr Opin Immunol. 2010;22:41-7.

10. Panne D, Maniatis T, Harrison SC. An atomic model of the interferon-beta enhanceosome. Cell. 2007;129:1111-23.

11. Borgeling Y, Schmolke M, Viemann D, Nordhoff C, Roth J, Ludwig S. Inhibition of p38 mitogen-activated protein kinase impairs influenza virus-induced primary and secondary host gene responses and protects mice from lethal H5N1 infection. J Biol Chem. 2014;289:13-27.

12. Waas WF, Lo HH, Dalby KN. The kinetic mechanism of the dual phosphorylation of the ATF2 transcription factor by $\mathrm{p} 38$ mitogen-activated protein (MAP) kinase alpha. Implications for signal/response profiles of MAP kinase pathways. J Biol Chem. 2001;276:5676-84.

13. Szretter KJ, Gangappa S, Belser JA, Zeng H, Chen H, Matsuoka Y, et al. Early control of $\mathrm{H} 5 \mathrm{~N} 1$ influenza virus replication by the type I interferon response in mice. J Virol. 2009;83:5825-34. 
14. Koerner I, Kochs G, Kalinke U, Weiss S, Staeheli P. Protective role of beta interferon in host defense against influenza A virus. J Virol. 2007;81:2025-30.

15. Kato $H$, Takeuchi O, Sato S, Yoneyama M, Yamamoto M, Matsui K, et al. Differential roles of MDA5 and RIG-I helicases in the recognition of RNA viruses. Nature. 2006;441:101-5.

16. Loo YM, Fornek J, Crochet N, Bajwa G, Perwitasari O, Martinez-Sobrido L, et al. Distinct RIG-I and MDA5 signaling by RNA viruses in innate immunity. J Virol. 2008;82:335-45.

17. Kato H, Sato S, Yoneyama M, Yamamoto M, Uematsu S, Matsui K, et al. Cell typespecific involvement of RIG-I in antiviral response. Immunity. 2005;23:19-28.

18. Hui KP, Lee SM, Cheung CY, Mao H, Lai AK, Chan RW, et al. H5N1 influenza virus-induced mediators upregulate RIG-I in uninfected cells by paracrine effects contributing to amplified cytokine cascades. J Infect Dis. 2011;204:1866-78.

19. Meduri GU, Kohler G, Headley S, Tolley E, Stentz F, Postlethwaite A. Inflammatory cytokines in the BAL of patients with ARDS. Persistent elevation over time predicts poor outcome. Chest. 1995;108:1303-14.

20. Schutte H, Lohmeyer J, Rosseau S, Ziegler S, Siebert C, Kielisch H, et al. Bronchoalveolar and systemic cytokine profiles in patients with ARDS, severe pneumonia and cardiogenic pulmonary oedema. Eur Respir J. 1996;9:1858-67.

21. Kotenko SV, Gallagher G, Baurin VV, Lewis-Antes A, Shen M, Shah NK, et al. IFNlambdas mediate antiviral protection through a distinct class II cytokine receptor complex. Nat Immunol. 2003;4:69-77.

22. Domanski $P$, Witte $M$, Kellum $M$, Rubinstein $M$, Hackett $R$, Pitha $P$, et al. Cloning and expression of a long form of the beta subunit of the interferon alpha beta receptor that is required for signaling. J Biol Chem. 1995;270:21606-11.

23. Platanias LC, Fish EN. Signaling pathways activated by interferons. Exp Hematol. 1999;27:1583-92.

24. Katze MG, Fornek JL, Palermo RE, Walters KA, Korth MJ. Innate immune modulation by RNA viruses: emerging insights from functional genomics. Nat Rev Immunol. 2008;8:644-54.

25. Xiao H, Killip MJ, Staeheli P, Randall RE, Jackson D. The human interferon-induced MxA protein inhibits early stages of influenza $A$ virus infection by retaining the incoming viral genome in the cytoplasm. J Virol. 2013;87:13053-8.

26. Li S, Min JY, Krug RM, Sen GC. Binding of the influenza A virus NS1 protein to PKR mediates the inhibition of its activation by either PACT or double-stranded RNA. Virology. 2006;349:13-21.

27. min JY, Krug RM. The primary function of RNA binding by the influenza A virus NS1 protein in infected cells: Inhibiting the $2^{\prime}-5^{\prime}$ oligo (A) synthetase/RNase L pathway. Proc Natl Acad Sci USA. 2006;103:7100-5.

28. Pauli EK, Schmolke M, Wolff T, Viemann D, Roth J, Bode JG, et al. Influenza A virus inhibits type I IFN signaling via NF-kappaB-dependent induction of SOCS-3 expression. PLoS Pathog. 2008;4:e1000196.

29. Wei H, Wang S, Chen Q, Chen Y, Chi X, Zhang L, et al. Suppression of interferon lambda signaling by SOCS-1 results in their excessive production during influenza virus infection. PLoS Pathog. 2014;10:e1003845.

30. Lee B, Robinson KM, McHugh KJ, Scheller EV, Mandalapu S, Chen C, et al. Influenza-induced type I interferon enhances susceptibility to gram-negative and gram-positive bacterial pneumonia in mice. Am J Physiol Lung Cell Mol Physiol. 2015;309:L158-67.

31. Davidson S, Crotta S, McCabe TM, Wack A. Pathogenic potential of interferon alphabeta in acute influenza infection. Nat Commun. 2014;5:3864.

32. Hogner K, Wolff T, Pleschka S, Plog S, Gruber AD, Kalinke U, et al. Macrophageexpressed IFN-beta contributes to apoptotic alveolar epithelial cell injury in severe influenza virus pneumonia. PLoS Pathog. 2013;9:e1003188.

33. Goritzka M, Durant LR, Pereira C, Salek-Ardakani S, Openshaw PJ, Johansson C. Alpha/beta interferon receptor signaling amplifies early proinflammatory cytokine production in the lung during respiratory syncytial virus infection. J Virol. 2014;88:6128-36.

34. Channappanavar R, Fehr AR, Vijay R, Mack M, Zhao J, Meyerholz DK, et al. Dysregulated type I interferon and inflammatory monocyte-macrophage responses cause lethal pneumonia in SARS-CoV-infected mice. Cell Host Microbe. 2016;19:181-93.

35. Zhou Z, Li X, Liu J, Dong L, Chen Q, Liu J, et al. Honeysuckle-encoded atypical microRNA2911 directly targets influenza A viruses. Cell Res. 2015;25:39-49.

36. Hu J, Ma W, Li N, Wang KJ. Antioxidant and anti-inflammatory flavonoids from the flowers of Chuju, a medical cultivar of Chrysanthemum morifolim Ramat. J Mex Chem Soc. 2017;61:282-9.

37. Sun C, Wang Y, Zhang X. Taraxacum mongolicum extract exhibits antimicrobial activity against respiratory tract bacterial strains in vitro and in neonatal rats by enhancing systemic Th1 immunity. Trop J Pharm Res. 2018;17:1833-8.

38. Law AH, Yang CL, Lau AS, Chan GC. Antiviral effect of forsythoside A from Forsythia suspensa (Thunb.) Vahl fruit against influenza A virus through reduction of viral M1 protein. J Ethnopharmacol. 2017;209:236-47.
39. Li J, Zhou B, Li C, Chen Q, Wang Y, Li Z, et al. Lariciresinol-4-O-beta-D-glucopyranoside from the root of Isatis indigotica inhibits influenza $A$ virus-induced proinflammatory response. J Ethnopharmacol. 2015;174:379-86.

40. Weihrauch JL, Gardner JM. Sterol content of foods of plant origin. J Am Diet Assoc. 1978;73:39-47.

41. Piironen V, Toivo J, Lampi AM. Natural sources of dietary plant sterols. J Food Composition Anal. 2000;13:619-24.

42. Yoshida Y, Niki E. Antioxidant effects of phytosterol and its components. J Nutr Sci Vitaminol. 2003;49:277-80.

43. Plat J, Hendrikx T, Bieghs V, Jeurissen ML, Walenbergh SM, van Gorp PJ, et al. Protective role of plant sterol and stanol esters in liver inflammation: insights from mice and humans. PLoS One. 2014;9:e110758.

44. Kim KA, Lee IA, Gu W, Hyam SR, Kim DH. beta-Sitosterol attenuates high-fat dietinduced intestinal inflammation in mice by inhibiting the binding of lipopolysaccharide to toll-like receptor 4 in the NF-kappaB pathway. Mol Nutr Food Res. 2014;58:963-72.

45. Moon DO, Lee KJ, Choi YH, Kim GY. Beta-sitosterol-induced-apoptosis is mediated by the activation of ERK and the downregulation of Akt in MCA-102 murine fibrosarcoma cells. Int Immunopharmacol. 2007;7:1044-53.

46. Dudek SE, Nitzsche K, Ludwig S, Ehrhardt C. Influenza A viruses suppress cyclooxygenase- 2 expression by affecting its mRNA stability. Sci Rep. 2016:6:27275

47. Livak KJ, Schmittgen TD. Analysis of relative gene expression data using real-time quantitative PCR and the 2(-Delta Delta C(T)) method. Methods. 2001;25:402-8.

48. Gaur P, Munjhal A, Lal SK. Influenza virus and cell signaling pathways. Med Sci Monit. 2011;17:Ra148-54.

49. Hui KP, Lee SM, Cheung CY, Ng IH, Poon LL, Guan Y, et al. Induction of proin flammatory cytokines in primary human macrophages by influenza $A$ virus (H5N1) is selectively regulated by IFN regulatory factor 3 and p38 MAPK. Immunol. 2009;182:1088-98.

50. Droebner K, Reiling SJ, Planz O. Role of hypercytokinemia in NF-kappaB p50deficient mice after H5N1 influenza A virus infection. J Virol. 2008;82:11461-6.

51. Coulombe F, Jaworska J, Verway M, Tzelepis F, Massoud A, Gillard J, et al. Targeted prostaglandin $E 2$ inhibition enhances antiviral immunity through induction of type I interferon and apoptosis in macrophages. Immunity. 2014;40:554-68.

52. Lee SM, Cheung CY, Nicholls JM, Hui KP, Leung CY, Uiprasertkul $M$, et al. Hyperinduction of cyclooxygenase-2-mediated proinflammatory cascade: a mechanism for the pathogenesis of avian influenza H5N1 infection. J Infect Dis. 2008;198:525-35.

53. Rehwinkel J, Tan CP, Goubau D, Schulz O, Pichlmair A, Bier K, et al. RIG-I detects viral genomic RNA during negative-strand RNA virus infection. Cell. 2010;140:397-408.

54. Jiang $L$, Zhang NN, Ding F, Li XY, Chen L, Zhang HX, et al. RA-inducible gene-I induction augments STAT1 activation to inhibit leukemia cell proliferation. Proc Natl Acad Sci USA. 2011;108:1897-902.

55. Borden EC, Sen GC, Uze G, Silverman RH, Ransohoff RM, Foster GR, et al. Interferons at age 50: past, current and future impact on biomedicine. Nat Rev Drug Disco. 2007;6:975-90.

56. Davidson S, Maini MK, Wack A. Disease-promoting effects of type I interferons in viral, bacterial, and coinfections. J Interferon Cytokine Res. 2015;35:252-64.

57. Besch R, Poeck H, Hohenauer T, Senft D, Hacker G, Berking C, et al. Proapoptotic signaling induced by RIG-I and MDA-5 results in type I interferon-independent apoptosis in human melanoma cells. J Clin Invest. 2009;119:2399-411.

58. Lee N, Wong CK, Chan PK, Chan MC, Wong RY, Lun SW, et al. Cytokine response patterns in severe pandemic $2009 \mathrm{H} 1 \mathrm{~N} 1$ and seasonal influenza among hospitalized adults. PLoS One. 2011;6:e26050.

59. Capelozzi VL, Parra ER, Ximenes M, Bammann RH, Barbas CS, Duarte MI. Pathological and ultrastructural analysis of surgical lung biopsies in patients with swine-origin influenza type $\mathrm{A} / \mathrm{H} 1 \mathrm{~N} 1$ and acute respiratory failure. Clinics. 2010;65:1229-37.

60. La Gruta NL, Kedzierska K, Stambas J, Doherty PC. A question of self-preservation: immunopathology in influenza virus infection. Immunol Cell Biol. 2007;85:85-92.

61. Gack MU, Shin YC, Joo CH, Urano T, Liang C, Sun L, et al. TRIM25 RING-finger E3 ubiquitin ligase is essential for RIG-I-mediated antiviral activity. Nature. 2007;446:916-20.

62. Honda K, Takaoka A, Taniguchi T. Type I inteferon gene induction by the interferon regulatory factor family of transcription factors. Immunity. 2006;25:349-60.

63. Onomoto $\mathrm{K}$, Yoneyama M, Fung G, Kato H, Fujita T. Antiviral innate immunity and stress granule responses. Trends Immunol. 2014;35:420-8.

64. Lee DC, Cheung CY, Law AH, Mok CK, Peiris M, Lau AS. p38 mitogen-activated protein kinase-dependent hyperinduction of tumor necrosis factor alpha expression in response to avian influenza virus H5N1. J Virol. 2005;79:10147-54

65. Schmolke M, Viemann D, Roth J, Ludwig S. Essential impact of NF-kappaB signaling on the H5N1 influenza A virus-induced transcriptome. J Immunol. 2009;183:5180-9. 
66. N'Guessan PD, Hippenstiel S, Etouem MO, Zahlten J, Beermann W, Lindner D, et al. Streptococcus pneumoniae induced p38 MAPK- and NF-kappaB-dependent COX-2 expression in human lung epithelium. Am J Physiol Lung Cell Mol Physiol. 2006;290:L1131-8.

67. Onoguchi K, Yoneyama M, Takemura A, Akira S, Taniguchi T, Namiki H, et al. Viral infections activate types I and III interferon genes through a common mechanism. J Biol Chem. 2007;282:7576-81.

68. Jiang $M$, Osterlund $P$, Fagerlund R, Rios DN, Hoffmann A, Poranen MM, et al. MAP kinase p38alpha regulates type III interferon (IFN-lambda1) gene expression in human monocyte-derived dendritic cells in response to RNA stimulation. J Leukoc Biol. 2015;97:307-20.

69. Mikkelsen SS, Jensen SB, Chiliveru S, Melchjorsen J, Julkunen I, Gaestel M, et al. RIG-I-mediated activation of p38 MAPK is essential for viral induction of interferon and activation of dendritic cells: dependence on TRAF2 and TAK1. J Biol Chem. 2009;284:10774-82.

70. Wang J, Basagoudanavar SH, Wang X, Hopewell E, Albrecht R, Garcia-Sastre A, et al. NF-kappa B RelA subunit is crucial for early IFN-beta expression and resistance to RNA virus replication. J Immunol. 2010;185:1720-9.

71. Imaizumi T, Kumagai M, Taima K, Fujita T, Yoshida H, Satoh K. Involvement of retinoic acid-inducible gene-I in the IFN-\{gamma\}/STAT1 signalling pathway in BEAS-2B cells. Eur Respir J. 2005;25:1077-83.

72. Dempoya J, Matsumiya T, Imaizumi T, Hayakari R, Xing F, Yoshida $H$, et al. Doublestranded RNA induces biphasic STAT1 phosphorylation by both type I interferon (IFN)-dependent and type I IFN-independent pathways. J Virol. 2012;86:12760-9.

73. Randall RE, Goodbourn S. Interferons and viruses: an interplay between induction, signalling, antiviral responses and virus countermeasures. J Gen Virol. 2008;89:1-47.

74. Sadler AJ, Williams BR. Interferon-inducible antiviral effectors. Nat Rev Immunol. 2008;8:559-68.

75. Wang F, Xu L, Feng X, Guo D, Tan W, Zhang M. Interleukin-29 modulates proinflammatory cytokine production in synovial inflammation of rheumatoid arthritis. Arthritis Res Ther. 2012;14:R228.

76. Bernardo AR, Cosgaya JM, Aranda A, Jimenez-Lara AM. Synergy between RA and TLR3 promotes type I IFN-dependent apoptosis through upregulation of TRAIL pathway in breast cancer cells. Cell Death Dis. 2013;4:e479.

77. Sato K, Hida S, Takayanagi H, Yokochi T, Kayagaki N, Takeda K, et al. Antiviral response by natural killer cells through TRAIL gene induction by IFN-alpha/beta. Eur J Immunol. 2001;31:3138-46.
78. Korteweg C, Gu J. Pathology, molecular biology, and pathogenesis of avian influenza A (H5N1) infection in humans. Am J Pathol. 2008;172:1155-70.

79. Kandasamy M, Suryawanshi A, Tundup S, Perez JT, Schmolke M, Manicassamy S, et al. RIG-I Slgnaling Is Critical for Efficient Polyfunctional T cell responses during influenza virus infection. PLoS Pathog. 2016;12:e1005754.

80. Pang IK, Pillai PS, Iwasaki A. Efficient influenza A virus replication in the respiratory tract requires signals from TLR7 and RIG-I. Proc Natl Acad Sci USA. 2013;110:13910-5.

81. Kohlmeier JE, Cookenham T, Roberts AD, Miller SC, Woodland DL. Type I interferons regulate cytolytic activity of memory $\mathrm{CD}^{+} \mathrm{T}$ cells in the lung airways during respiratory virus challenge. Immunity. 2010;33:96-105.

82. Ishikawa $E$, Nakazawa $M$, Yoshinari M, Minami M. Role of tumor necrosis factorrelated apoptosis-inducing ligand in immune response to influenza virus infection in mice. J Virol. 2005;79:7658-63.

83. Littwitz $\mathrm{E}$, Francois $\mathrm{S}$, Dittmer U, Gibbert K. Distinct roles of NK cells in viral immunity during different phases of acute Friend retrovirus infection. Retrovirology. 2013;10:127.

84. Hussell T, Openshaw PJ. Intracellular IFN-gamma expression in natural killer cells precedes lung $\mathrm{CD} 8^{+} \mathrm{T}$ cell recruitment during respiratory syncytial virus infection. J Gen Virol. 1998;79:2593-601.

85. Wiley JA, Cerwenka A, Harkema JR, Dutton RW, Harmsen AG. Production of interferon-gamma by influenza hemagglutinin-specific CD8 effector $T$ cells influences the development of pulmonary immunopathology. Am J Pathol. 2001;158:119-30.

86. Kim JE, Bauer S, La KS, Lee KH, Choung JT, Roh KH, et al. $\mathrm{CD}^{+} / \mathrm{CD}^{+} \mathrm{T}^{\mathrm{Tym}}-$ phocytes imbalance in children with severe 2009 pandemic influenza A (H1N1) pneumonia. Korean J Pediatr. 2011;54:207-11.

87. Enelow RI, Mohammed AZ, Stoler MH, Liu AN, Young JS, Lou YH, et al. Structural and functional consequences of alveolar cell recognition by $\mathrm{CD} 8^{+} \mathrm{T}$ lymphocytes in experimental lung disease. J Clin Invest. 1998;102:1653-61.

88. Maelfait J, Roose K, Vereecke L, Mc Guire C, Sze M, Schuijs MJ, et al. A20 deficiency in lung epithelial cells protects against influenza $A$ virus infection. PLoS Pathog. 2016;12:e1005410.

89. Pinto R, Herold S, Cakarova L, Hoegner K, Lohmeyer J, Planz O, et al. Inhibition of influenza virus-induced NF-kappaB and Raf/MEK/ERK activation can reduce both virus titers and cytokine expression simultaneously in vitro and in vivo. Antivir Res. 2011;92:45-56. 